\title{
Sheep husbandry in the early Neolithic of the Pyrenees: New data on feeding and reproduction in the cave of Chaves
}

\author{
Alejandro Sierra $^{\mathrm{a}, \mathrm{b},{ }^{*}}$, Marie Balasse ${ }^{\mathrm{c}}$, Florent Rivals ${ }^{\mathrm{d}, \mathrm{e}, \mathrm{f}}$, Denis Fiorillo ${ }^{\mathrm{c}}$, Pilar Utrilla ${ }^{\mathrm{b}}$, \\ Maria Saña ${ }^{a}$ \\ ${ }^{a}$ Laboratori d'Arqueozoologia, Departament de Prehistòria, Edifici B Facultat Filosofia i Lletres, Autonomous University of Barcelona, 08193 Barcelona, Spain \\ ${ }^{\mathrm{b}}$ Primeros Pobladores y Patrimonio Arqueológico del Valle del Ebro, Universidad de Zaragoza, 50009 Zaragoza, Spain \\ c AASPE « Archéozoologie, Archéobotanique: Sociétés, Pratiques, Environnements » UMR 7209 CNRS MNHN, 75005 Paris, France \\ d ICREA, Pg. Lluís Companys 23, 08010 Barcelona, Spain \\ ${ }^{\mathrm{e}}$ Institut Català de Paleoecologia Humana i Evolució Social (IPHES-CERCA), Zona Educacional 4, Campus Sescelades URV (Edifici W3), 43007 Tarragona, Spain \\ ${ }^{\mathrm{f}}$ Universitat Rovira i Virgili (URV), Departament d'Història i Història de l'Art, Avinguda de Catalunya 35, 43002 Tarragona, Spain
}

\section{A R T I C L E I N F O}

\section{Keywords:}

Sheep

Stable carbon and oxygen isotopes

Enamel bioapatite

Microwear

Reproduction

Feeding

Iberian Peninsula

Early Neolithic

\begin{abstract}
A B S T R A C T
Sheep predominate the Early Neolithic faunal assemblages in the Iberian Peninsula. Their exploitation for meat and milk production made them key to the economy of these early farming societies. Management of sheep breeding season and feeding in the context of the local environment were decisive in obtaining these livestock products. This work focuses on these aspects through stable isotope and dental microwear analyses on sheep teeth from the cave of Chaves (Huesca, Spain). The results show the existence of "out of season" (autumn/early winter) sheep births in the Early Neolithic, contrasting significantly with spring lambing prevailing in Neolithic husbandries elsewhere in Europe and confirming the antiquity of a western Mediterranean characteristic in this regard. Furthermore, little changes in sheep diet throughout the year have been documented, as far as could be evidenced from stable carbon isotope ratios and dental microwear. Only two individuals showed higher variability in diet on a seasonal scale with possible contribution of $\mathrm{C}_{4}$ plants, possibly from grazing in the valley steppes at lower altitudes. Overall the results suggest good adaptation of sheep to the Pyrenean mid-altitude environment and strong zootechnical knowledge of the earliest shepherds in this area.
\end{abstract}

\section{Introduction}

Sheep were an important component of the earliest husbandries in the Mediterranean. This species was introduced relatively quickly into the Iberian Peninsula, together with goats, cattle and pigs (Saña, 2013; Saña et al., 2020). Around 5600-5400 cal BC, domestic animals are attested in the whole Iberian Peninsula, from the Mediterranean to the Atlantic coasts. Domestic caprines were the most abundant in the Early Neolithic herds in the Iberian Peninsula, among which sheep predominated goat in almost all sites (Saña et al., 2020). Sheep were exploited mainly for meat and milk (Debono Spiteri et al., 2016; Sierra et al., 2019). This species was a fundamental part of the small-scale mixed intensive farming system proposed for the Early Neolithic in the Iberian Peninsula (Antolín, 2016, 2015; Antolín et al., 2018), in which livestock farming would have been intensive and with multipurpose animal exploitation (Antolín et al., 2014; Sierra et al., 2019), resembling systems described for other Mediterranean regions such as Greece (Halstead, 2006, 1996, 1981). In this model, agriculture and animal husbandry would be interconnected. Animal husbandry would have been restricted to crop fields (because woodland clearings are limited), where small numbers of sheep would have been grazed at some time of the year, resulting in direct manuring (Halstead 1981). Animal husbandry would have been diversified into different species and different products (meat, milk and traction) (Halstead 1996), as documented in the Neolithic period on the Iberian Peninsula (Antolín et al., 2014; Helmer et al., 2018; Sierra et al., 2019). Intensively managed herds would generally be kept on the settlement, especially during the winter. During these periods, they would have to be fed with fodder, which could consist of stems, leaves, branches, grains or by-products of the various stages of crop processing (Halstead 1998).

\footnotetext{
* Corresponding author at: Laboratori d'Arqueozoologia, Departament de Prehistòria, Edifici B Facultat Filosofia i Lletres, Autonomous University of Barcelona, 08193 Barcelona, Spain

E-mail address: asierrasainzaja@gmail.com (A. Sierra).
} 
The livestock management practices of the earliest farming societies in the Iberian Peninsula have been little addressed. Studies involving stable isotope analysis, increasingly commonly used to investigate husbandry practices, have been scarce and focused in the northeast of the Iberia. These studies have shown the existence of different husbandry management regimes for pigs in different sites of the Early Neolithic (Navarrete et al., 2017) and different food regimes for cattle, goats and sheep at the La Draga site (Navarrete et al., 2019). It seems that during the Early Neolithic there were various livestock management practices related to the herding of different species, the exploitation of different livestock products and adaptation to the different Iberian environments.

In this research context, the cave of Chaves (Central Pyrenees; $5600-4900$ cal BC) (Utrilla and Laborda, 2018) provides some of the earliest evidence for the introduction of sheep into the Iberian Peninsula, with dates similar to the oldest ones on the Mediterranean coast. The site is located within the Ebro basin in the first mountainous ranges of the central Pyrenees (elevation $640 \mathrm{~m}$ ). Its surroundings were characterized by the presence of an open forest (Alcolea et al., 2017; LópezGarcía, 1992; López-García and López-Sáez, 2000), with high altitude pastures to the north and steppe landscapes to the south. This situation allowed for the combined exploitation of the valley and the mountain (Alcolea et al., 2017) providing access to multiple resources. At Chaves, sheep were quickly adopted and were the most abundant of the livestock. This species was exploited for meat and milk, as indicated by the mortality profiles (Sierra et al. 2019).

The present study aims at characterizing in more details Early Neolithic sheep husbandry at Chaves on the seasonal scale, focusing on the management of animal breeding and feeding. Wild herbivores have a seasonal breeding strategy due to the underlying physiological mechanisms of animal adaptation to environmental conditions (Chemineau et al., 2008). Today, although sheep have retained a strongly seasonal reproduction, some sheep breeds originating from the Mediterranean area can lamb in the autumn, bringing benefits in terms of out-of-season availability of animal products (Gómez-Brunet et al., 2012; Valls Ortiz, 1983). Recent research has shown autumn lambing in the Early Neolithic of Southern France, in the Epicardial occupations at Taï (altitude $54 \mathrm{~m}$; 5270-4990 cal BC) and Gazel (250 m; 5350-5050 cal BC) in the Languedoc region (Tornero et al., 2020). This important finding implies both the physiological adaptation of sheep and intentional management by the herders, implying skills in the manipulation of socio-sexual signals in sheep herds (Tornero et al., 2020). One objective of our study was to determine whether autumn lambing may also have occurred at Chaves, in an earlier context and in different environmental settings in a middle mountain location.

In addition, this work aimed to evaluate the feeding regimes of the Chaves sheep taking into account the exploited landscape around Chaves, the herd feeding management strategies and their role in the management of the breeding season. Domestic herds feeding management of fundamental for livestock production. Both the availability of forage resources and the dietary requirements of herds change seasonally. Ruminants are adapted to seasonal variations of food. Despite this adaptation, feeding is key for the meat and milk production (MorandFehr et al., 2007), the herds health and reproduction (Lamy et al., 2012). Fecundation (Abecia et al., 2006), gestation, birth, and lactation are risk stages (in which they require more energy) for females (Kilgour et al., 2008; Kind et al., 2006; Meikle et al., 2018; Rosa and Bryant, 2003), for what feeding must be controlled to ensure the survival of the offspring. Especially in a context where autumn lambing could be envisaged and will be investigated, a special attention could have been given to winter food provisioning, aiming at reducing weight loss in prevision to spring mating (Tornero et al., 2020).

\section{Background}

\subsection{Investigating sheep diet}

Sheep are ruminants. Ruminants are divided into three groups, browsers or concentrate selectors, grazers or grass and roughage eaters and mixed feeders or intermediate opportunistic (Hofmann, 1989). Sheep are considered grazers, with a preferential diet of grasses in certain environments (Balasse and Ambrose, 2005; Hofmann, 1989), but can also be fed browse (Papachristou, 1997; Redding, 1981). Browse can also be included in the form of tree branch fodder as a seasonal complementation to face the scarcity of grass resources, reflecting a specific intervention by the herders and the exploitation of a specific part of the landscape (forested areas).

The analysis of stable carbon isotopes in bioapatite $\left(\delta^{13} \mathrm{C}\right)$ has been used previously to determine the feeding patterns of domestic herds. Carbon is incorporated into tissues from plant intake (Lee-Thorp and van der Merwe, 1991; Tieszen, 1991). The measurement of stable carbon isotope ratios $\left({ }^{13} \mathrm{C} /{ }^{12} \mathrm{C}\right)$ allows distinguishing between different plant types in diet, including the reliance on plants with different photosynthetic processes such as $\mathrm{C}_{3}$ and $\mathrm{C}_{4}$ grasses. Most of the grasses in the Iberian Peninsula are $\mathrm{C}_{3}$, but there is a small proportion of $\mathrm{C}_{4}$ grasses (Pyankov et al., 2010), specifically those from the Chenopodiaceae and Amaranthaceae families (Domínguez-Llovería, 2011; Sanz-Elorza, 2009). Today, plants from these families are documented in arid areas such as those in the lowlands and middle mountain of the Ebro basin (between 200 and $800 \mathrm{~m}$, although they can reach up to 1500) but do not occur in the mountain due to lower temperatures at higher elevations. Potential seasonal variations in the relative contribution of these different plant resources in sheep diet, as a tracer of mobility between the lowlands and the highlands, may be reconstructed through sequential analysis in enamel (Balasse et al., 2002; Navarrete et al., 2019; Tornero et al., 2020). Moreover, $\delta^{13} \mathrm{C}$ values also allow to characterize the feeding environment in which the animals are fed, distinguishing between plants grown in open and closed environments: the later are characterized by significantly lower stable carbon isotope ratios due to the canopy effect (Bonafini et al., 2013; Drucker et al., 2008; Drucker and Bocherens, 2009; van der Merwe and Medina, 1991).

Dental microwear is a technique that attempts to identify and quantify the microtraces present on the occlusal surface of the tooth enamel (Mainland, 1998a; Solounias and Semprebon, 2002). These microtraces allow the inference of the diet in the last intakes, which is called the "Last Supper" effect (Grine, 1986; Mainland, 1998b). These marks are usually scratches and pits with different morphology. Depending on their relative occurrences, one can distinguish between browsers, grazers or mixed-feeders, and try to reconstruct the landscape in which the species live and feed. Dental microwear has been used since the last decades applied to wild animals, to know diet and paleoenvironment (Rivals et al., 2009). The application to domestic species is less common. A greater variability in dental microwear in domestic animals due to human intervention is challenging the method (Gallego-Valle et al., 2020; Jiménez-Manchón et al., 2020; Mainland, 2006, 2003, 1998a).

The combined use of sequential stable isotope analysis and microwear analysis allows different levels of time resolution and qualitive assessement. On the one hand, the sequential isotopic analysis in enamel allows tracing dietary changes occurred during the period of tooth formation, which covers the first years of life in sheep molars (Milhaud and Nezit, 1991; Weinreb and Sharav, 1966), with a multiple season record. On the other hand, dental microwear analysis allows investigation of diet over the last days or weeks before death, and also enables to specify diet abrasiveness and the relative proportion of browse and graze (Grine 1986, Mainland 1998b), which cannot be defined using stable carbon isotopes in $\mathrm{C}_{3}$ environments. 


\subsection{Investigating sheep birth seasonality}

The reproduction of mammals tends to be seasonal due to physiological mechanisms that allow them to adapt to environmental fluctuations. Births occur when the environmental conditions are better for the survival of the female and offspring (Santiago-Moreno et al., 2006). In the case of sheep, the seasonality is very marked in high and middle latitudes (Rosa and Bryant, 2003). Domestication has extended the reproductive period with respect to their wild ancestors (Balasse et al., 2017a; Hafez, 1952). The seasonality is regulated by different factors, among which the photoperiod is the most important (Karsch et al., 1984). Other aspects such as temperature, feeding, male and females interactions, lambing date and lactation period have a modulating effect (Rosa and Bryant, 2003). Consequently the reproductive cycle (the alternation of a fertile period and a sexual rest period) vary with latitudes but also between breeds (Hafez, 1952), some traits being hereditary (Chemineau et al., 2008). In temperate Europe the annual fertility periods are short and lead to winter/spring lambing. By contrast, in some Mediterranean breeds a longer fertility period allows breeding in the spring, leading to autumn lambing (Chemineau, 1993; Hadjikoumis et al., 2018; Tornero et al., 2020). In particular, most of the current breeds in the Iberian Peninsula have long fertility periods (Forcada et al., 1992; Gómez-Brunet et al., 2012; Valls Ortiz, 1983). Recent work has shown a prolonged period of breeding for sheep in the Early Neolithic of Southern France with autumn/winter births (Tornero et al., 2020), contrasting to all other Neolithic Europeans sites from higher latitudes where lambing was restricted to late winter/spring (Balasse et al., 2020, 2017b).

Research on sheep reproduction in the Neolithic has focused on establishing the seasonality of births and the length of the birth period, seeking to demonstrate the adaptability of domestic species to new environments and the management and the exploitation of livestock resources by the prehistoric agropastoral societies (Balasse et al., 2020, $2017 \mathrm{~b}$ ). These works are based on the sequential analysis of $\delta^{18} \mathrm{O}$ values in the bioapatite of dental enamel. Oxygen is fixed in tissues from ingested water (Iacumin and Longinelli, 2002; Longinelli, 1984; Luz et al., 1984). Oxygen stable isotope ratios in precipitation vary according to ambient temperature and rainfall amount. Sequential analysis of tooth enamel allows reconstructing the seasonal variations in the $\delta^{18} \mathrm{O}$ values recorded over the period of mineralization of tooth enamel (Balasse et al., 2002, 2003).

\section{Materials}

\subsection{Site}

Cave of Chaves (Bastarás, Huesca; Fig. 1) is located in Sierra de Guara, the highest sector of the Central Pre-Pyrenees, at $640 \mathrm{~m}$ above sea level. This is a conglomerate cave with a mouth $60 \mathrm{~m}$ wide by $30 \mathrm{~m}$ high and a depth of $225 \mathrm{~m}$ (Baldellou, 2012; Utrilla and Laborda, 2018). It has Solutrean and Magdalenian occupations, but the most outstanding feature is the Early Neolithic sequence, with two levels (1a and 1b) whose radiocarbon dates overlap in a 500-year sequence (Utrilla and Laborda, 2018). The Early Neolithic occupation goes from 5600 to 4800 cal BC. The earliest level (1b) is dated between 5600 and $5300 \mathrm{cal} \mathrm{BC}$ and the most recent level (1a) between 5300 and 4800 cal BC. These levels stand out for the richness of their materials, with potteries bearing Cardial decorations of Mediterranean influence, a rich lithic and bone industry with a large number of polished axes and an important set of spoons and spurs on bone support. In addition, the painted pebbles or with traces of ochre (Utrilla and Baldellou, 2007, 2001) and a burial in a pit, dated to 5308-5057 cal BC (Utrilla et al., 2008), stand out. The diet of buried humans shows a high animal protein intake by all individuals (Villalba-Mouco et al., 2018). Finally, the faunal assemblage, with over

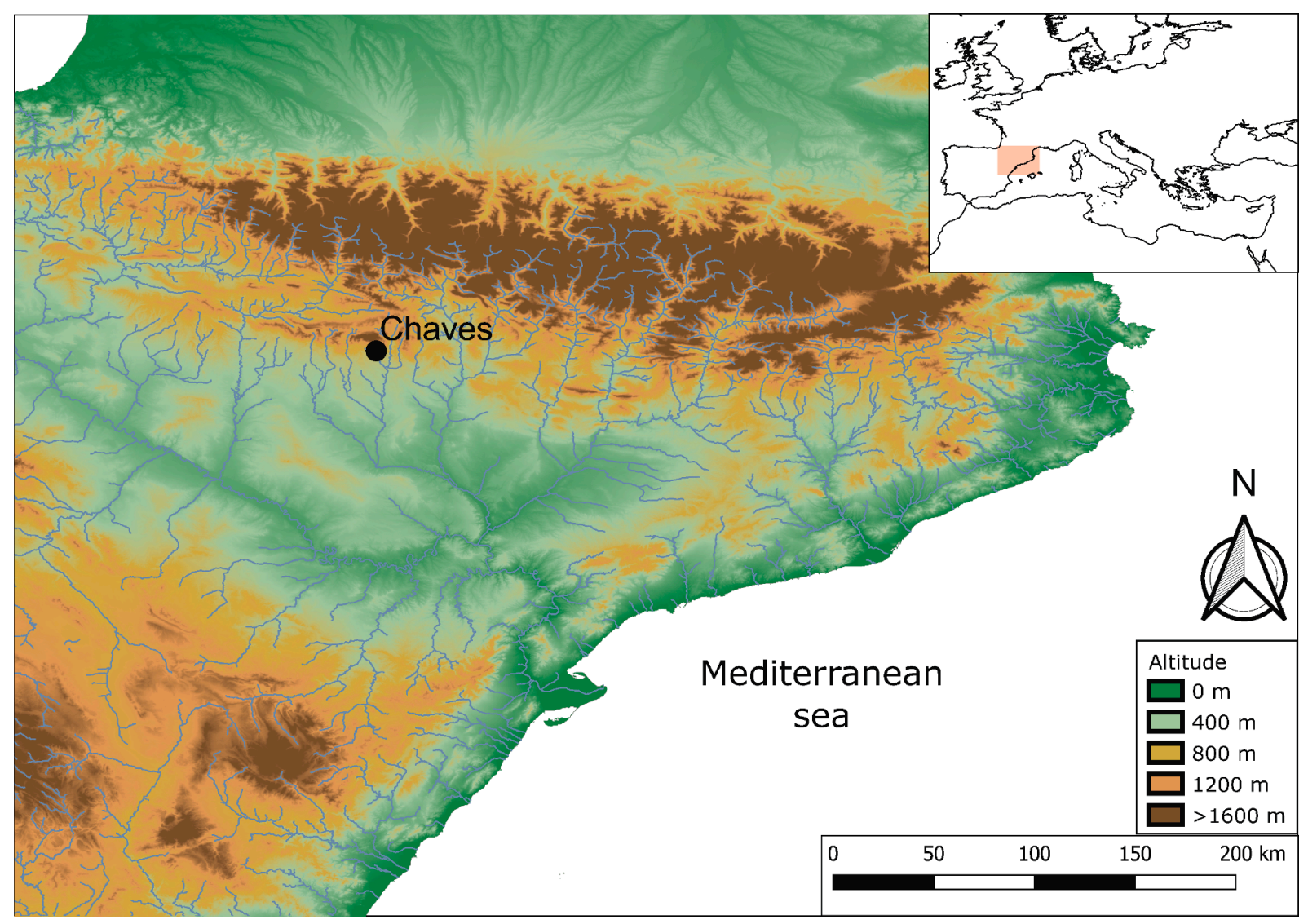

Fig. 1. Map showing location of Chaves in Ebro basin and Iberian Peninsula. 
12,000 identified remains (Castaños, 2004) is one of the most important for the Early Neolithic in the Iberian Peninsula. Among the fauna remains, those of sheep are the most abundant, both at level $1 \mathrm{a}$ and $1 \mathrm{~b}$, being only comparable with other sites such as La Draga (Saña, 2011), Cueva de Sarsa (Boessneck and Von den Driesch, 1980), Cueva de l'Or (Pérez Ripoll, 1980) or Nerja (Liesau and Morales, 2012). The landscape around Chaves in the Early Neolithic (1b level) was characterized by a slightly open forest (Arboreal Pollen 40-60\%) dominated by pine forests and mixed oak forests. The presence of mesophyte tree species (Acer, Alnus, Tilia and Corylus) and Mediterranean shrubs (Arbutus unedo, Fabaceae and Phillyrea/ Rhamnus) was also documented (Alcolea et al., 2017; López-García, 1992; López-García and López-Sáez, 2000). Permanence of the habitat within the cave is reflected from spaces defined for different uses, a diversity of lithic instruments and carried out activities, the variety of ceramic forms, and the presence of hearths, storage structures and cobbled floors (Utrilla and Laborda, 2018).

\subsection{Samples}

Sheep teeth were selected for microwear and sequential stable isotope analyses (Table 1). Morphological criteria were used to distinguish sheep from goats (Balasse and Ambrose, 2005; Gillis et al., 2011; Halstead et al., 2002; Helmer, 2000; Payne, 1985; Zeder and Pilaar, 2010). A total of 14 lower molars of 12 sheep ( 8 seconds molars and 6 third molars) were selected for isotope analysis. Most of them were slaughtered between 24 and 48 months (Sierra et al., 2019) Table 1). All of them belong to level $1 \mathrm{~b}$ except for individual $\mathrm{CH}$ Ovis 5 , belonging to level 1a. A total of 59 dental remains were selected for dental microwear analysis. All teeth analysed for stable isotope ratios were analysed for microwear. Of these, 30 were sheep belonging to different age classes (C: 6-12 months; SD: 12-36 months; EF: 24-48 months; G: 48-72 months; HI: more than 72 months). The remaining samples were cattle (Bos taurus) (7), red deer (Cervus elaphus) (8), roe deer (Capreolus capreolus) (5) and the Iberian ibex (Capra pyrenaica) (9). The aim of the presence of these other species is to enable comparison of the results with other domestic and wild ruminants, with different food preferences (grazers: cattle and Iberian ibex, mixed feeding: red deer; browsers: roe deer) (Hofmann, 1989).

\section{Methods}

\subsection{Stable isotope analysis}

A sequential sampling was performed on the molar buccal side, on the posterior lobe of M2 and on the middle lobe of M3 following the procedure described in Balasse et al. (2002). The lobe surfaces were cleaned by abrasion with tungsten drills. The enamel was sequentially drilled using a diamond bit perpendicular to the tooth growth axis from

\section{Table 1}

General information about the specimens selected for stable isotope analysis. Age has been calculated using Payne $(1987,1973)$ and Jones (2006).

\begin{tabular}{|c|c|c|c|c|c|c|}
\hline \multirow[t]{2}{*}{ ID } & \multirow[t]{2}{*}{ Teeth } & \multirow[t]{2}{*}{ Side } & \multirow{2}{*}{$\frac{\text { Payne }}{\text { classes }}$} & \multirow{2}{*}{$\frac{\text { Payne }}{\text { age }}$} & \multirow{2}{*}{$\frac{\text { Jones }}{\text { classes }}$} & \multirow{2}{*}{$\frac{\text { Jones }}{\text { age }}$} \\
\hline & & & & & & \\
\hline CH Ovis 1 & $\mathrm{M}_{2}$ & $\mathrm{R}$ & $\mathrm{E}$ & $24-36 \mathrm{~m}$ & $\mathrm{E} 1 / 2$ & $19-36 \mathrm{~m}$ \\
\hline CH Ovis 2 & $\mathrm{M}_{2}-\mathrm{M}_{3}$ & $\mathrm{R}$ & $\mathrm{E}$ & $24-36 \mathrm{~m}$ & E3+ & $22-42 \mathrm{~m}$ \\
\hline CH Ovis 3 & $\mathrm{M}_{2}$ & $\mathrm{~L}$ & $\mathrm{EF}$ & $24-48 \mathrm{~m}$ & - & \\
\hline $\mathrm{CH}$ Ovis 4 & $\mathrm{M}_{2}$ & $\mathrm{R}$ & D & $12-24 \mathrm{~m}$ & D6+ & $14-27 \mathrm{~m}$ \\
\hline $\mathrm{CH}$ Ovis 5 & $\mathrm{M}_{2}-\mathrm{M}_{3}$ & $\mathrm{R}$ & $\mathrm{F}$ & $24-36 \mathrm{~m}$ & F9/10 & - \\
\hline CH Ovis 6 & $\mathrm{M}_{2}$ & $\mathrm{R}$ & $\mathrm{E}$ & $24-36 \mathrm{~m}$ & E3+ & $22-42 \mathrm{~m}$ \\
\hline CH Ovis 7 & $\mathrm{M}_{2}$ & $\mathrm{~L}$ & E & $24-36 \mathrm{~m}$ & - & - \\
\hline CH Ovis 8 & $\mathrm{M}_{2}$ & $\mathrm{R}$ & $\mathrm{E}$ & $24-36 \mathrm{~m}$ & $\mathrm{E} 1 / 2$ & $19-36 \mathrm{~m}$ \\
\hline CH Ovis 9 & $\mathrm{M}_{3}$ & $\mathrm{~L}$ & G & $48-72 \mathrm{~m}$ & - & - \\
\hline CH Ovis 10 & $\mathrm{M}_{3}$ & $\mathrm{~L}$ & $\mathrm{~F}$ & $36-48 \mathrm{~m}$ & $\mathrm{~F} 5 / 8$ & $30-54 \mathrm{~m}$ \\
\hline CH Ovis 11 & $\mathrm{M}_{3}$ & $\mathrm{R}$ & $\mathrm{F}$ & $36-48 \mathrm{~m}$ & $\mathrm{~F} 9 / 10$ & $42-66 \mathrm{~m}$ \\
\hline CH Ovis 12 & $\mathrm{M}_{3}$ & $\mathrm{R}$ & $\mathrm{F}$ & $36-48 \mathrm{~m}$ & $\mathrm{~F} 9 / 10$ & $42-66 \mathrm{~m}$ \\
\hline
\end{tabular}

the apex to the enamel-root junction. A low magnification lens $(\times 3)$ was used throughout the sampling process. The sampling covers the entire height of the crown and the samples are spaced at intervals of 1-1.5 mm. Each sample covers a horizontal band less than one millimetre wide that perforates the entire thickness of the enamel layer. The samples were located in tooth crown using their distance from the cervix of the crown.

The samples were pre-treated to eliminate diagenetic carbonates $(4 \mathrm{~h}$ in $0.1 \mathrm{M}$ acetic acid [CH3COOH]; $0.1 \mathrm{ml}$ solution / $1 \mathrm{mg}$ sample) according to the protocol in Balasse et al. (2002) modified in Tornero et al. (2013). The pretreated enamel powders were analysed in a Kiel IV device connected to a DeltaVAdvantage IRMS. The accuracy and precision of the measurements were verified using an internal laboratory calcium carbonate standard (Marbre LM standardized according to the international standard NBS 19). The results are expressed in V-PDB. The analytical precision within each run, estimated from four to eight analyses of Marbre LM, was on average $0.04 \%$ for $\delta^{18} \mathrm{O}$ values and $0.02 \%$ for $\delta^{13} \mathrm{C}$ values. Over the period of analysis of the Chaves enamel samples, the analysis of 103 Marbre LM gave an average $\delta^{18} \mathrm{O}$ value of $-1.99 \pm 0.04 \%$ o (expected value $-1.83 \%$ ) and $+2.16 \pm 0.03 \%$ o (expected value $+2.13 \%$ ).

Finally, the $\delta^{18} \mathrm{O}$ sequences were modelled using an equation derived from a cosine function described in Balasse et al., (2012) using four parameters: the position of the maximum $\delta{ }^{18} \mathrm{O}$ value $\left(\mathrm{x}_{0}\right)$; the period of the cycle (X; distance over which one annual cycle was recorded); the amplitude of the signal (A) and the mean (M). The cycle period (X) was used to normalize $\mathrm{x}_{0}$ in order to eliminate inter-individual variability in tooth size (Balasse et al., 2012). The $\mathrm{x}_{0} / \mathrm{X}$ ratio varies with the season of birth. The season of birth is estimated by comparison with reference $\mathrm{x}_{0} /$ $\mathrm{X}$ ratios obtained in modern sheep (Balasse et al., 2020). All results are shown using a circular representation to reflect the cyclical nature of seasonality (Balasse et al., 2020).

\subsection{Dental microwear}

The methodology of Solounias and Semprebon (2002) was followed. First, the negative moulds of the selected teeth were made with high resolution dental silicone (Provil@novo Light $\mathrm{CD}$ ) and then a second layer using low resolution dental silicone (Provil $囚$ novo Putty). For the positive moulds, pure transparent epoxy resin was used (C.T.S. ${ }^{\circledR}$ EPO 150 resin and K 151 catalyst) (Camarós et al., 2016; Solounias and Semprebon, 2002). The positive moulds were analysed using a Zeiss Stemi 2000C stereomicroscope in the facilities of IPHES (Catalan Institute of Human Paleoecology and Social Evolution), illuminated with the CL1500 ECO light source. The images have been taken with the DeltaPix Invenio 5SII camera. The samples were analyzed by AS under the supervision of FR. The observations were made twice in different parts of the protoconid of the selected lower molars and premolars, having as reference a $0.4 \times 0.4 \mathrm{~mm}$ grid. The following variables, used in previous studies (Gallego et al., 2017; Jiménez-Manchón et al., 2018; Rivals et al., 2011), are: number of pits; number of scratches; number of small and large pits; number of fine and coarse scratches; the range of thickness of the scratches or SWS (scratch width score), distinguishing between predominance of fine scratches $(0)$, predominance of coarse scratches (2) and the same amount of fine and coarse scratches (1); the presence of more than four cross scratches (CS); and the presence of depressions of irregular circumference or gouges $(G)$. The numbers of scratches and pits allows distinction between grazers and browsers. To compare between both types of diets, the database of modern wild animals of Solounias and Semprebon (2002) was used. The R script created by Rivals (2019) was used for the elaboration of the microwear graphs.

\section{Results}

\subsection{Stable isotope analysis}

The results from the measurements of stable carbon and oxygen 
isotope ratios are shown in Table 2 and Fig. 2.

\subsubsection{Oxygen isotope ratios}

Overall, the $\delta^{18} \mathrm{O}$ values vary between $-5.3 \%$ and $2.8 \%$. In the second molars, the mid-range values vary between $0.5 \%$ and $-3.2 \%$, and the amplitude of intra-tooth variation is between $2.1 \%$ and $4.7 \%$. In the third molars, the mid-range $\delta^{18} \mathrm{O}$ value varies between $-0.4 \%$ and $-3.1 \%$, and the amplitude of intra-tooth variation is between $2.9 \%$ and $5.5 \%$.

The intra-tooth $\delta^{18} \mathrm{O}$ sequences for both M2 and M3 vary according to a sinusoidal pattern, which probably reflects the seasonal cycle, with the lowest values in the cold season and the highest in the warm season.

\subsubsection{Modelling of the $\delta^{18} \mathrm{O}$ sequences}

Results from the modelling of the $\delta^{18} \mathrm{O}$ sequences and the normalized location in tooth crown of the $\delta^{18} \mathrm{O}$ sequence optimum $\left(\mathrm{x}_{0} / \mathrm{X}\right)$ are shown in the Supplementary materials. CH Ovis $3 \mathrm{M} 2$, CH Ovis $4 \mathrm{M} 2$ and $\mathrm{CH}$ Ovis $12 \mathrm{M} 3$ could not be modelled due to truncated sequences. A duration of the births period of 0.35 year (or 4.2 months) is documented from the M2 where the $\mathrm{x}_{0} / \mathrm{X}$ ratios vary between 0.94 (or -0.06 ) and 0.29 . For the $M 3$, a duration of 0.42 year (or 5.1 months) is documented with $\mathrm{x}_{0} / \mathrm{X}$ ratios varying between 0.07 and 0.49 (Figs. 3 and 4).

\subsubsection{Carbon isotope ratios}

For all teeth except $\mathrm{CH}$ Ovis 5 and the last samples of $\mathrm{CH}$ Ovis 9, the $\delta^{13} \mathrm{C}$ values vary between $-12 \%$ and $-10.5 \%$. In the second molars, the mid-range value varies between $-11 \%$ and $-11.4 \%$, and the intra-tooth variation is between $0.4 \%$ and $1.6 \%$. In third molars, the mid-range value varies between $-10.5 \%$ and $-11.4 \%$, and the intra-tooth variation is between $0.8 \%$ and $1.2 \%$.

Fig. 2 shows intra-tooth variations in the $\delta^{13} \mathrm{C}$ values in the second and third molars. Leaving aside $\mathrm{CH}$ Ovis 5 and the last samples of $\mathrm{CH}$ Ovis 9, all remaining individuals have very similar values that vary between $-12 \%$ and $-10.5 \%$, within a range of $1.6 \%$ or the M2 and between $-12 \%$ and $-10 \%$, within a range of $2 \%$ for the M3. The maximum amplitude within each tooth does not exceed 1.6\%.

Individual $\mathrm{CH}$ Ovis 5, which was directly dated between 5294 and $5051 \mathrm{cal} \mathrm{BC}$, stands out with higher $\delta^{13} \mathrm{C}$ in both second and third molars (M2: $\max =9 \%$, $\min =10.2 \%$, mid-range $=-9.6 \%$; M3: $\max =-7.7 \%$, min $=-10.1 \%$, mid-range $=-8.9 \%$ o). Individual $\mathrm{CH}$ Ovis 9 also has higher values from $\delta^{13} \mathrm{C}$, especially in the part of the crown latest formed (M3: $\max =-8.9 \%$, $\min =-11.6 \%$, mid-range $=-10.3 \%$ ). Those could either reflect consumption of $\mathrm{C}_{3}$ plants from dry environments (Kohn, 2010) or the contribution in the diet of $\mathrm{C}_{4}$ plants (Cerling et al., 1993; Vogel, 1978).

\subsection{Microwear analysis}

Of the total 59 samples selected, 19 were discarded due to taphonomic alterations preventing the observation of microwear (El-Zaatari, 2010; King et al., 1999). These alterations resulted mainly from abrasion and erosion. Of the remaining 40 analyzed, 19 belonged to Ovis aries, 5 to Bos taurus, 6 to Cervus elaphus, 5 to Capreolus capreolus and 5 to Capra pyrenaica. Sheep are in different age stages $(\mathrm{C}=5 ; \mathrm{D}=2 ; \mathrm{DE}=1 ; \mathrm{EF}=9$; $\mathrm{G}=1 ; \mathrm{HI}=2$ ).

In general, all species are characterised by enamel surfaces with a low number of pits (Mean $=13.7$ ) and scratches (Mean =9.5) (Fig. 5). The scratches have a range between 4.5 and 19. The pits are between 6 and 29. The pits are more numerous than the scratches in all species except the Capra pyrenaica, where the number of scratches and pits is similar. The diet of these 5 species is very similar to each other, as the statistical tests show (Table 3 ). The variability of scratches is higher among wild animals than among domestic ones (Fig. 6), while in the pits these differences between wild and domestic animals are not observed (Table 4).

Sheep are characterized by a low number of pits $($ Mean $=16)$ and scratches $($ Mean $=7.5$ ). The number of scratches ranges from 4.5 to 13 , while the pits range from 8 to 29 . In $80 \%$ of individuals, the pits are more numerous than the scratches. In the range of scratch width score (SWS), fine scratches predominate in all but four individuals. Large pits (LP) are less numerous than small pits. In addition, the absence of crossed scratches (CS) and depressions of irregular circumference or gouges (G) is noteworthy. These data suggest a browsing diet for this species, although differences in feeding at different age stages have been detected. Younger animals (stage C: 6-12 months; stage D: 12-24 months, analysed the M1 of all individuals except one, which has been analysed in dp4) have fewer scratches than adults (stage EF: 24-48 months; stages G and HI: greater than 48 months) (Fig. 7) (MannWhitney $\mathrm{U}=12.5 ; \mathrm{p}=0.02$ ) but similar numbers of pits (Mann-Whitney $\mathrm{U}=37.5 ; \mathrm{p}=0.96$ ).

\section{Discussion}

\subsection{Seasonality of sheep births}

The season of sheep births at Chaves may be determined by comparison with the modern references with known dates of birth (Carmejane: Blaise \& Balasse 2011; Rousay: Balasse et al. 2012; Kemenez: Balasse et al., 2017b, 2020). Although the modern references are still incomplete and document mostly winter and spring births outside of the Mediterranean area, additional works are currently being undertaken to

Table 2

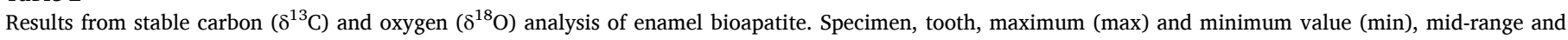
amplitude of intra-tooth variation (A). Table 2 .

\begin{tabular}{|c|c|c|c|c|c|c|c|c|}
\hline \multirow[b]{2}{*}{ Specimen } & \multicolumn{4}{|c|}{$\delta^{13} \mathrm{C}_{\text {VPDB }}(\%)$} & \multicolumn{4}{|c|}{$\delta^{18} \mathrm{O}_{\text {VPDB }}(\%)$} \\
\hline & Max & Min & Mid-range & A & Max & Min & Mid-range & A \\
\hline $\mathrm{CH}$ Ovis $1 \mathrm{M} 2$ & -10.94 & -11.91 & -11.42 & 0.97 & -1.52 & -4.94 & -3.23 & 3.42 \\
\hline $\mathrm{CH}$ Ovis $2 \mathrm{M} 2$ & -11.07 & -11.51 & -11.29 & 0.44 & 0.21 & -3.99 & -1.89 & 4.19 \\
\hline $\mathrm{CH}$ Ovis $3 \mathrm{M} 2$ & -10.57 & -11.45 & -11.01 & 0.88 & 1.81 & -2.16 & -0.17 & 3.97 \\
\hline $\mathrm{CH}$ Ovis $4 \mathrm{M} 2$ & -10.77 & -11.56 & -11.16 & 0.80 & -0.68 & -2.73 & -1.71 & 2.05 \\
\hline $\mathrm{CH}$ Ovis $5 \mathrm{M} 2$ & -9.02 & -10.21 & -9.61 & 1.18 & 2.79 & -1.88 & 0.45 & 4.67 \\
\hline $\mathrm{CH}$ Ovis $6 \mathrm{M} 2$ & -10.38 & -11.52 & -10.95 & 1.14 & 0.08 & -3.91 & -1.91 & 3.99 \\
\hline $\mathrm{CH}$ Ovis $7 \mathrm{M} 2$ & -10.55 & -11.71 & -11.13 & 1.16 & 0.36 & -2.71 & -1.17 & 3.07 \\
\hline CH Ovis $8 \mathrm{M} 2$ & -10.39 & -12.00 & -11.19 & 1.60 & -0.06 & -4.52 & -2.29 & 4.46 \\
\hline $\mathrm{CH}$ Ovis $9 \mathrm{M} 3$ & -8.92 & -11.58 & -10.25 & 2.66 & 0.68 & -3.64 & -1.48 & 4.32 \\
\hline CH Ovis $10 \mathrm{M} 3$ & -10.02 & -10.94 & -10.48 & 0.92 & -0.92 & -5.28 & -3.10 & 4.37 \\
\hline CH Ovis $11 \mathrm{M} 3$ & -10.87 & -12.02 & -11.44 & 1.15 & -0.79 & -3.68 & -2.23 & 2.88 \\
\hline $\mathrm{CH}$ Ovis $12 \mathrm{M} 3$ & -10.81 & -11.98 & -11.39 & 1.17 & 1.34 & -3.06 & -0.86 & 4.40 \\
\hline $\mathrm{CH}$ Ovis $5 \mathrm{M} 3$ & -7.67 & -10.09 & -8.88 & 2.42 & 2.38 & -3.10 & -0.36 & 5.49 \\
\hline $\mathrm{CH}$ Ovis $2 \mathrm{M} 3$ & -10.74 & -11.53 & -11.13 & 0.79 & 0.47 & -3.85 & -1.69 & 4.32 \\
\hline Min & -11.07 & -12.02 & -11.444 & 0.44 & -1.52 & -5.28 & -3.229 & 2.05 \\
\hline Max & -7.67 & -10.09 & -8.879 & 2.66 & 2.79 & -1.88 & 0.452 & 5.49 \\
\hline
\end{tabular}



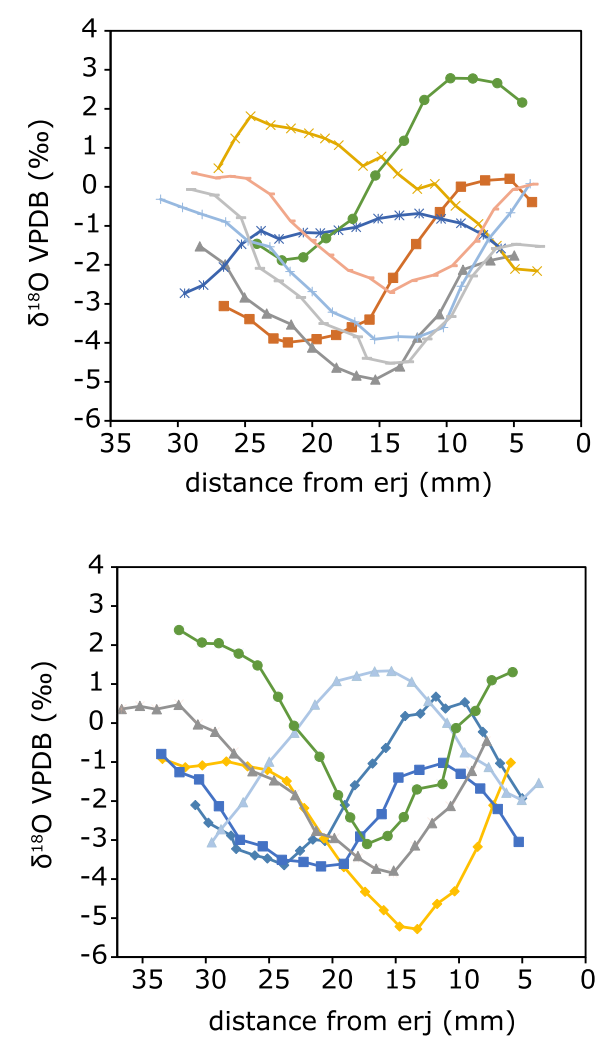

\section{Chaves Ovis M2}

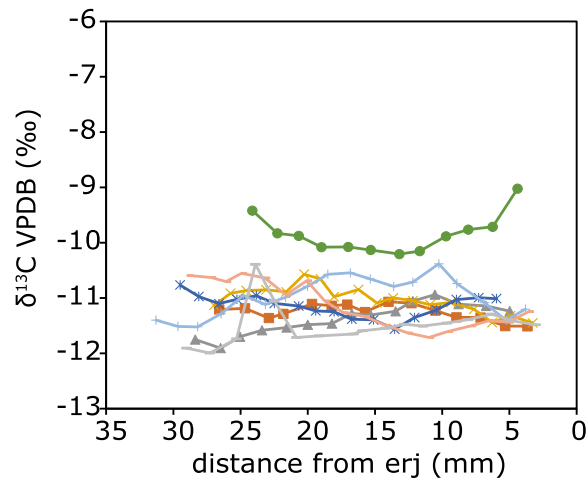

$-\mathrm{CH}$ Ovis $1 \mathrm{M} 2$
$-\mathrm{CH}$ Ovis $2 \mathrm{M} 2$
$-\mathrm{CH}$ Ovis $3 \mathrm{M} 2$
$* \mathrm{CH}$ Ovis $4 \mathrm{M2}$
$-\mathrm{CH}$ Ovis $5 \mathrm{M} 2$
$-\mathrm{CH}$ Ovis $6 \mathrm{M} 2$
$-\mathrm{CH}$ Ovis $7 \mathrm{M} 2$
$-\mathrm{CH}$ Ovis $8 \mathrm{M} 2$

\section{Chaves Ovis M3}

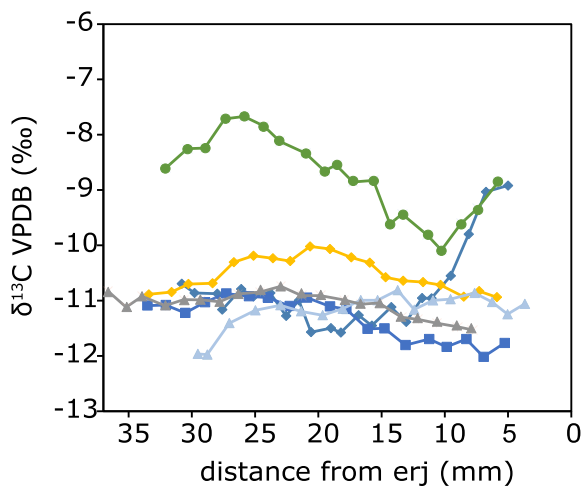

$\rightarrow-\mathrm{CH}$ Ovis $9 \mathrm{M3}$

$\rightarrow \mathrm{CH}$ Ovis $10 \mathrm{M} 3$

$\rightarrow \mathrm{CH}$ Ovis $11 \mathrm{M3}$

$-\mathrm{CH}$ Ovis 12 M3

$\rightarrow$ CH Ovis 5 M3

$₫ \mathrm{CH}$ Ovis 2 M3

Fig 2. Results from the sequential stable carbon and oxygen isotope analysis in second and third molar $\left(\mathrm{M}_{2}\right.$ and $\left.\mathrm{M}_{3}\right)$ enamel bioapatite. Each sample is located in the tooth crown relative to its distance from the enamel-root junction (ERJ).

\section{Chaves/modern sheep (x0/X ratio)}

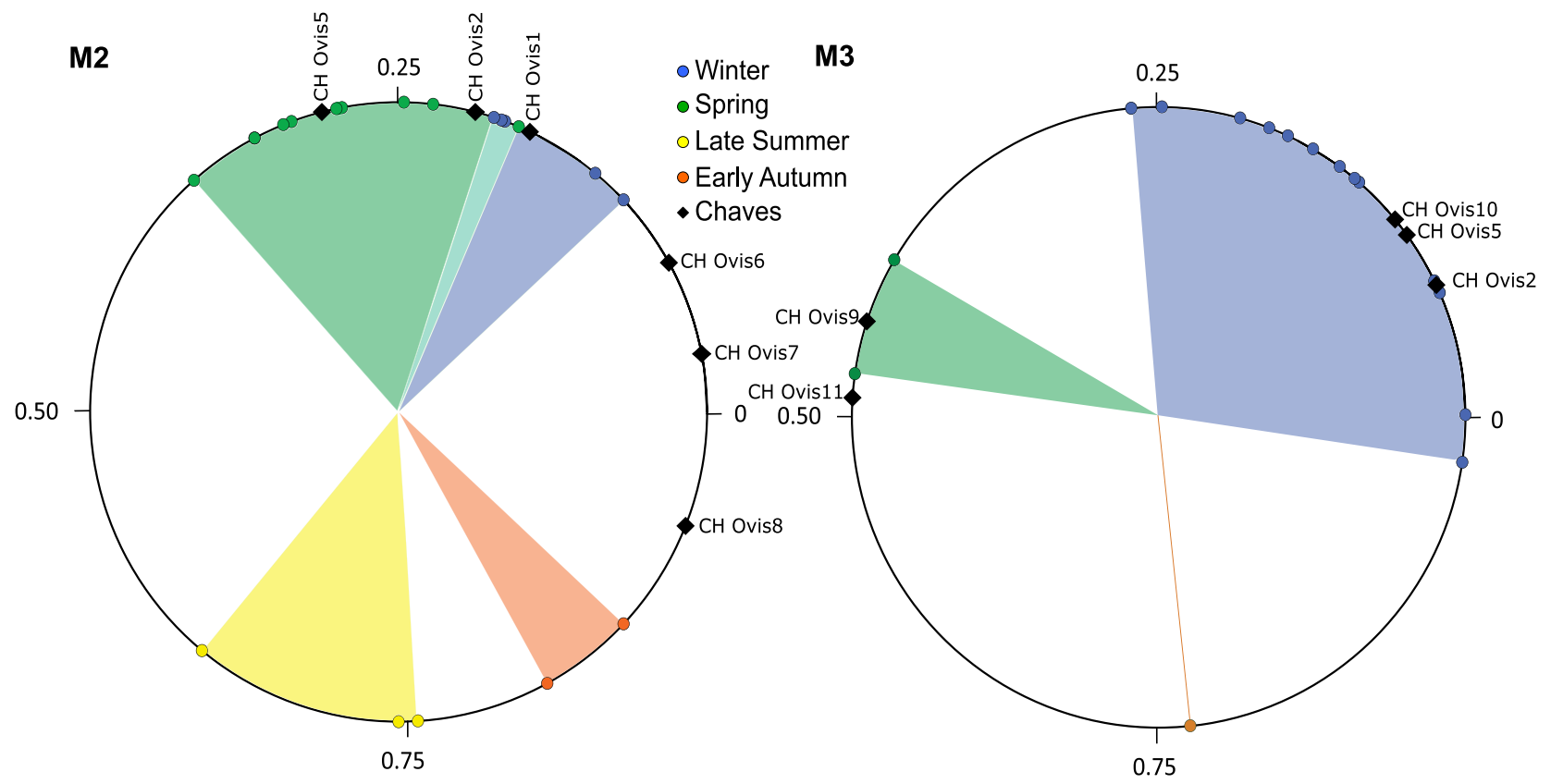

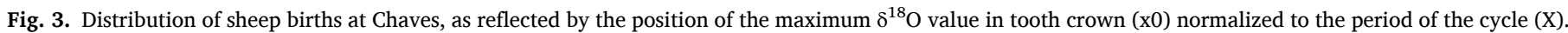

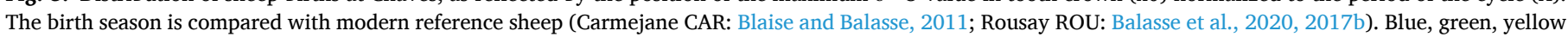
and orange color areas represent $\mathrm{x}_{0} / \mathrm{X}$ ratios obtained from modern specimens (colored dots). 


\section{Chaves/other European sites (x0/X ratio)}

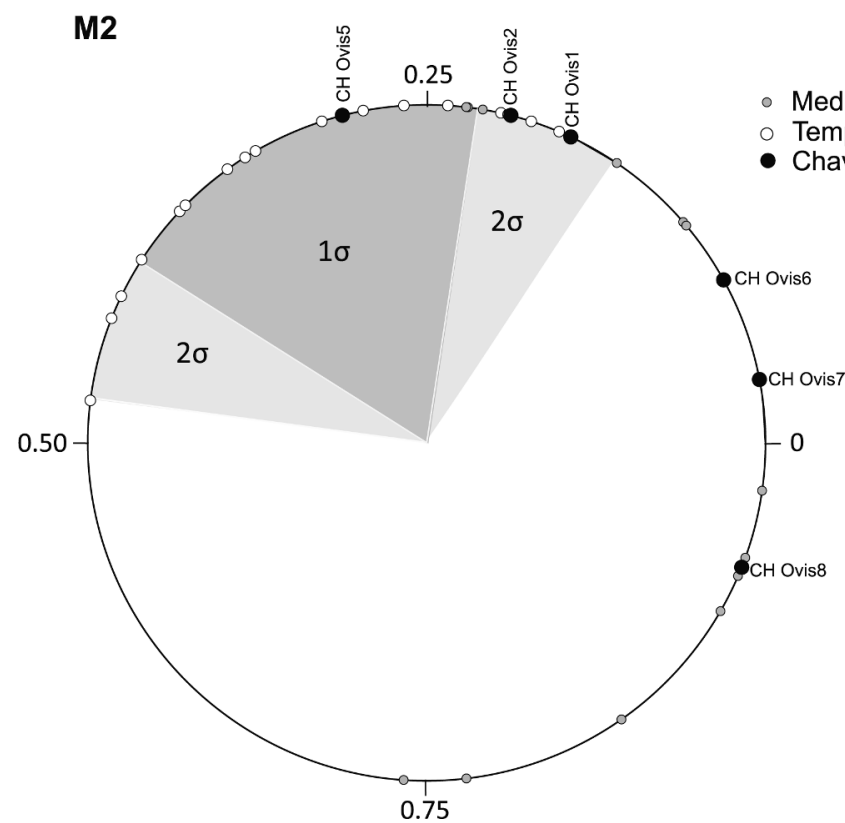

M3

Mediterranean sites

Temperate sites

Chaves

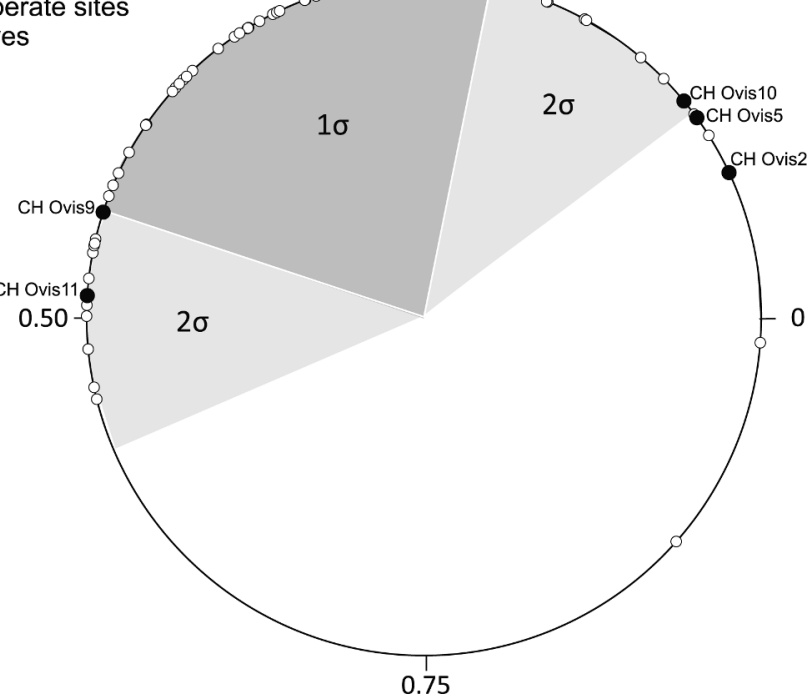

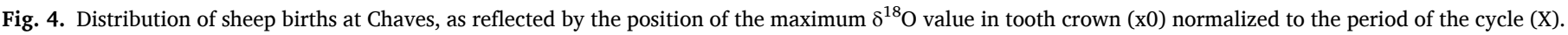

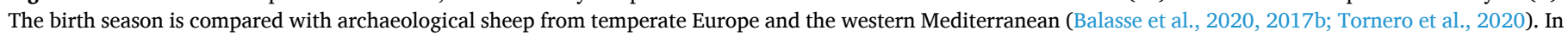
dark and light grey colors, the $1 \sigma$ and $2 \sigma$ confidence intervals reflect the time of the year when most sheep births occur outside of the Mediterranean area.

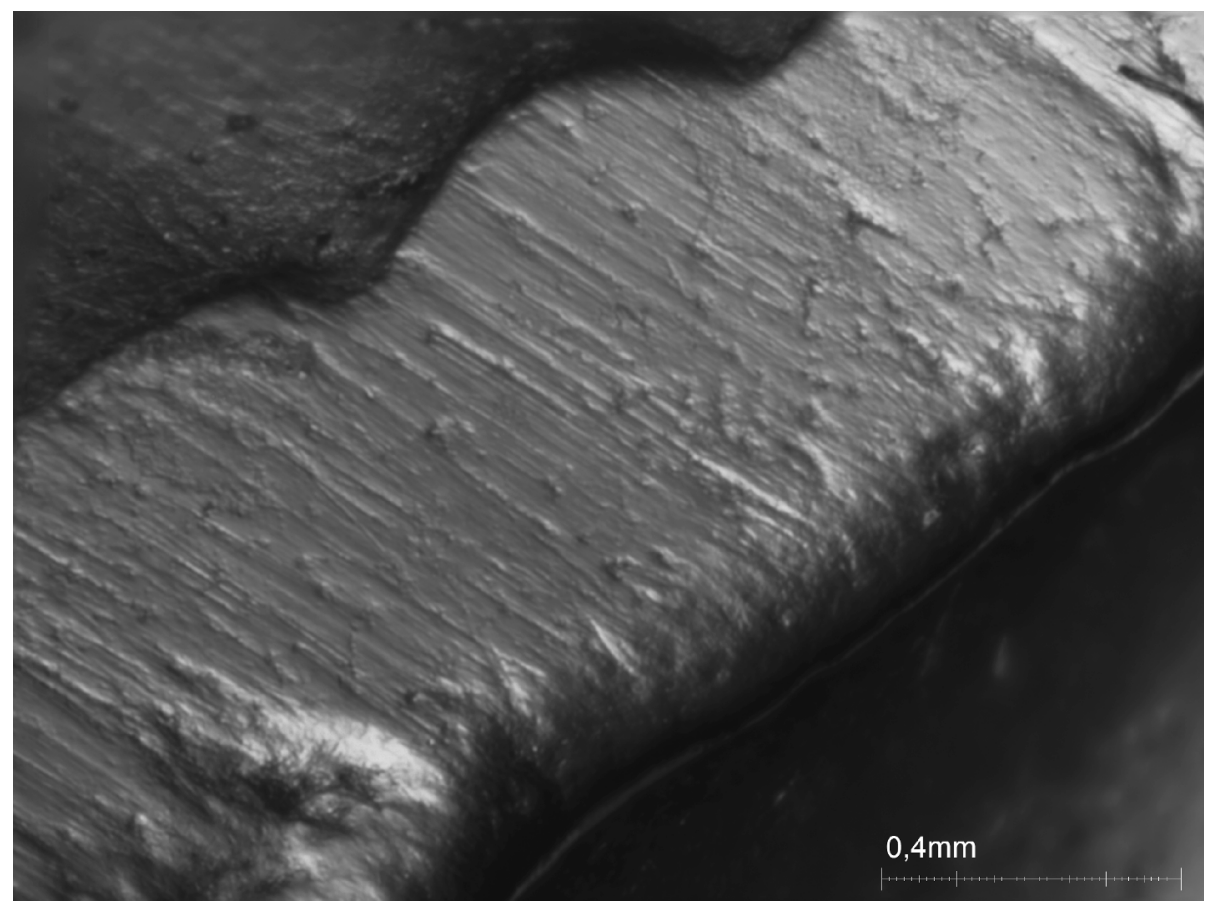

Fig. 5. Photomicrograph of occlusal surfaces of sheep's teeth at 35x magnification under a stereomicroscope.

complete them. Nevertheless, late summer/autumn births are represented by a few modern data (Fig. 3), and can also be extrapolated as occurring outside of the range of values obtained for winter/spring births. At Chaves, lambing occurred from the autumn to late spring. The timing of sheep births at Chaves is compared to other European sites dated between the 6 th and 4 th millennia BC on Fig. 4. The sheep births at Chaves typically occur within the time period defined at other western Mediterranean sites (Gazel and Taï, 43 N; Tornero et al., 2020) and at the margins of the lambing period defined at other locations in temperate Europe (latitudes $44-46^{\circ} \mathrm{N}$ ). Sheep births in autumn and early winter show an extension of the breeding season with respect to presentday as well as Neolithic sheep at higher latitudes. Autumn births are practiced in today's western Mediterranean sheep breeds, including in the Rasa aragonesa breed native to the same latitudes as Chaves sheep (Forcada et al., 1992; Gómez-Brunet et al., 2012; Valls Ortiz, 1983). The practice is also documented in medieval texts in the same latitudes 
Table 3

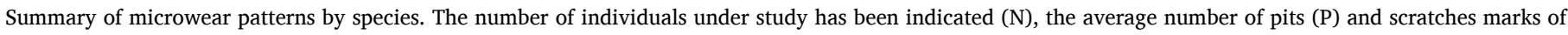

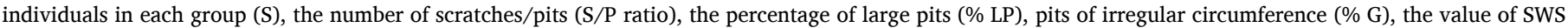
(scratch width score) for each species, cross scratches (\% XS) and the percentage of individuals with scratches mark counts between 0 and 17 (\% 0-17).

\begin{tabular}{|c|c|c|c|c|c|c|c|c|c|}
\hline Species & $\mathbf{N}$ & $\# \mathbf{P}$ & $\# \mathbf{S}$ & $\mathrm{S} / \mathrm{P}$ ratio & \%LP & $\% G$ & sws & $\%$ CS & $\% 0-17$ \\
\hline Ovis aries & 19 & 16 & 7.5 & 0.56 & 33.2 & 0 & 0.2 & 0 & 100 \\
\hline Bos taurus & 5 & 11.8 & 9.5 & 0.81 & 23 & 20 & 0.4 & 20 & 100 \\
\hline Cervus elaphus & 6 & 15.1 & 8.2 & 0.54 & 35 & 0 & 0.5 & 17 & 100 \\
\hline Capreolus capreolus & 5 & 15.1 & 11 & 0.71 & 34 & 20 & 0 & 0 & 100 \\
\hline Capra pyrenaica & 5 & 11 & 12 & 1.05 & 33 & 0 & 0 & 0 & 80 \\
\hline
\end{tabular}

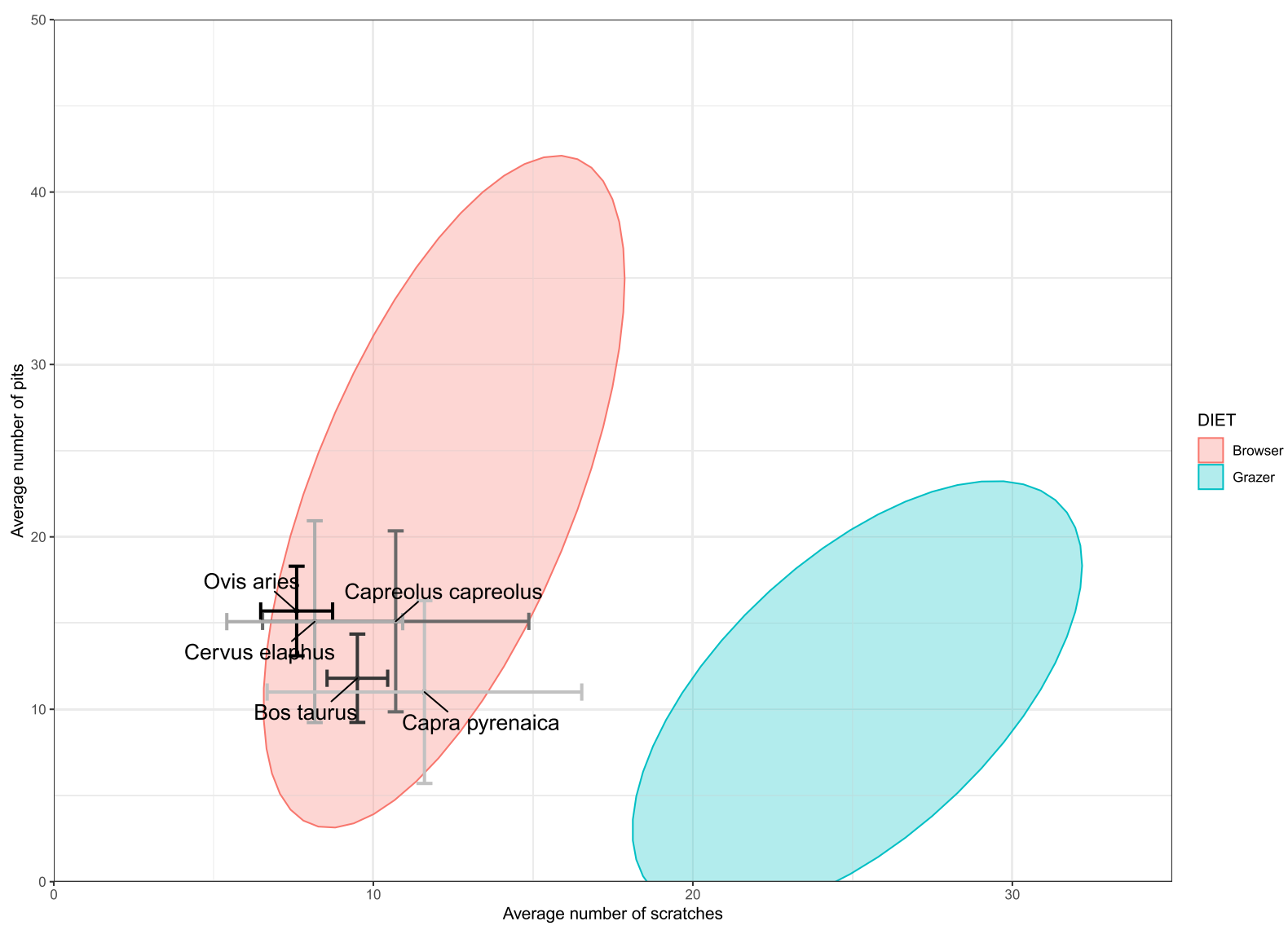

Fig. 6. Bivariate plot of the numbers of pits and scratches grouped by species. Error bars correspond to standard error of the mean ( \pm 1 SEM) for each sample.

Table 4

Microwear results Mann-Whitney test.

\begin{tabular}{|c|c|c|c|c|c|c|c|c|}
\hline \multirow[t]{2}{*}{ Mann-Whitney } & \multicolumn{2}{|l|}{ Bos taurus } & \multicolumn{2}{|c|}{ Cervus elaphus } & \multicolumn{2}{|c|}{ Capreolus capreolus } & \multicolumn{2}{|c|}{ Capra pyrenaica } \\
\hline & Scratches & Pits & Scratches & Pits & Scratches & Pits & Scratches & Pits \\
\hline Ovis aries & 0.06073 & 0.1734 & 0.76 & 0.784 & 0.1614 & 0.9729 & 0.08801 & 0.08279 \\
\hline Bos taurus & & & 0.4102 & 0.4102 & 1 & 0.5296 & 0.832 & 0.4633 \\
\hline Cervus elaphus & & & & & 0.3602 & 0.9269 & 0.1699 & 0.4632 \\
\hline Capreolus capreolus & & & & & & & 0.5993 & 0.2087 \\
\hline
\end{tabular}

(Fernández-Otal, 1993). Similar systems have been described in present day and as early as in the Pre-Pottery Neolithic period in Cyprus (Hadjikoumis et al., 2018). However, Cyprus lies at a latitude around $35^{\circ} \mathrm{N}$, implying a different photoperiod cycle allowing for a shorter sexual rest and a longer fertility period in sheep, providing herders with a wider margin to schedule lambing in autumn and winter (Hadjikoumis et al., 2018). The existence of such strategies in the Western Mediterranean at higher latitudes $\left(42-43^{\circ} \mathrm{N}\right)$ would have required an extended fertility period, overcoming in a way the photoperiodic control, and perhaps revealing a genetic capacity by sheep for it. Our results suggest that this particularity existed in the Early Neolithic, implying not only sheep physiological capability for an extended fertile period, but also human control on the females and males interactions. Additionally, human genetic selection may have contributed to the extension of the breeding season of Mediterranean sheep (Tornero et al., 2020).

The existence of the "Mediterranean" type lambing period in the Early Neolithic levels at Chaves has biological and economic implications. First, it may be meaningful in terms of the adaptability of sheep to the Iberian environment. A successful adaptation of sheep to the Iberian environment was already demonstrated by the predominance of this 


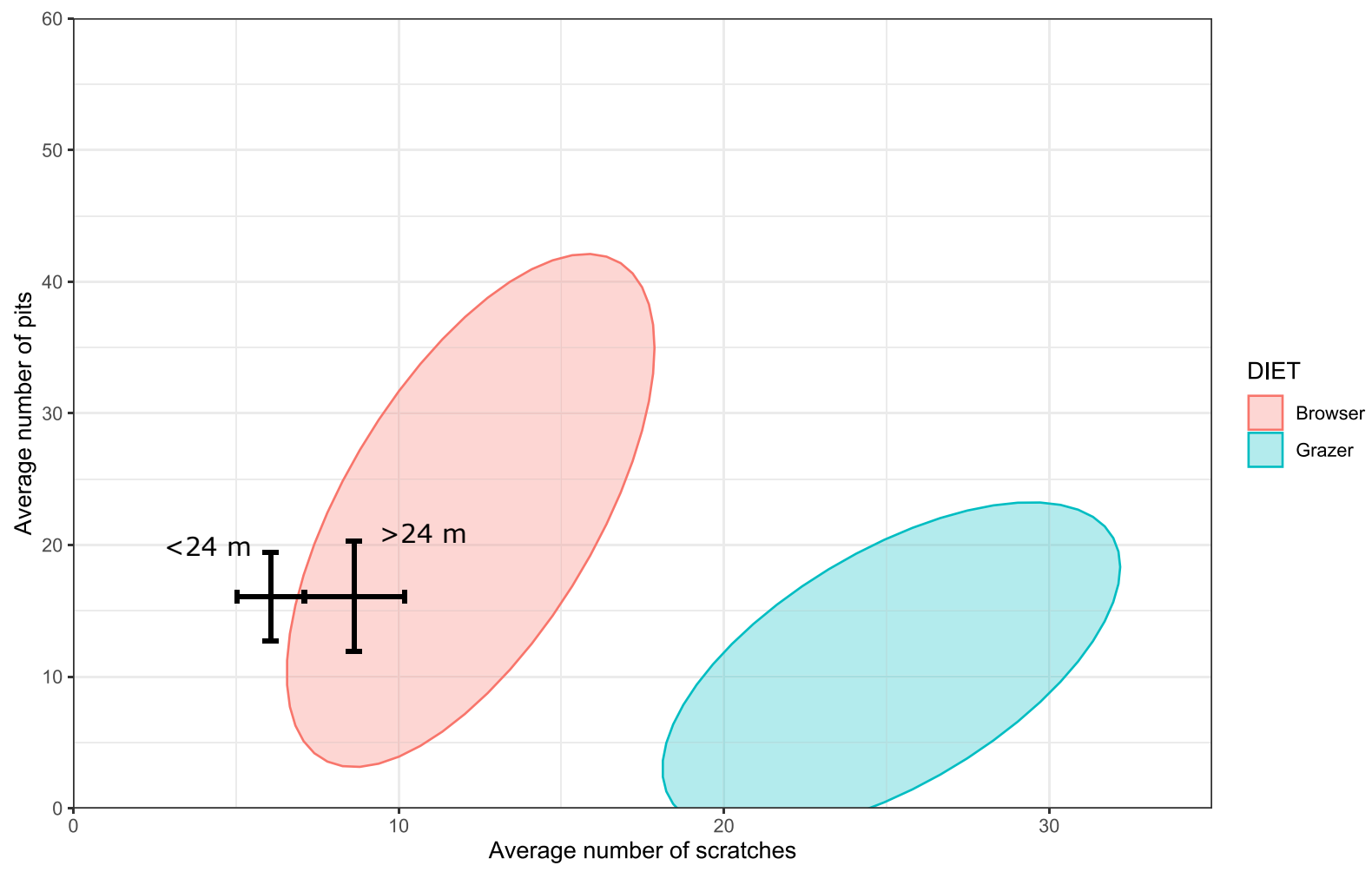

Fig. 7. Bivariate plot of the numbers of pits and scratches of sheep grouped by age. Error bars correspond to standard error of the mean ( \pm 1 SEM) for each sample.

species among domestic stock in the whole Iberian Peninsula during the Early Neolithic (Saña et al., 2020). At Chaves and in the Pyrenean area, warm winters, a higher level of humidity and frequent rainfall characterized the Mid-Holocene climate (González-Sampériz et al., 2017; Montes et al., 2016). This could have favoured autumnal lambing husbandry systems by providing grazing resources to support autumn and winter lactation. In addition to the biological implications, the length of the birth period would have had important advantages. Extending the birth season could be part of a husbandry strategy to make livestock products such as milk available over a longer period of time.

\subsection{Feeding}

\subsubsection{Stable carbon isotopes}

The $\delta^{13} \mathrm{C}$ values show, except for individuals $\mathrm{CH}$ Ovis 5 and 9 , a diet consisting of $\mathrm{C}_{3}$ plants from open environments (Bonafini et al., 2013; Drucker et al., 2008; Noe-Nygaard et al., 2005). Low intra-tooth variations ( 0.4 to $1.6 \%$ ) reflect a small amplitude of variation in diet $\delta^{13} \mathrm{C}$ values on the annual scale and no obvious alternation between different diets over the seasonal cycle. The low seasonal variability may have several explanations. On the one hand, seasonal variations in $\delta^{13} \mathrm{C}$ values of $\mathrm{C}_{3}$ plants is lower in some Mediterranean plants (Werner and Máguas, 2010). Tornero et al. (2018) found reduced variation in plant communities in mid- and high-altitude mountain locations. The variation in the $\delta^{13} \mathrm{C}$ values of the Vilamajor pastures, located at an altitude of $709 \mathrm{~m}$ in a mid-mountain landscape are around $-1.0 \%$ (Tornero et al., 2018). On the other hand, this may also reflect specific management of sheep diet by the farmers. At La Draga (Navarrete et al., 2019) a similarly low amplitude in the sheep diet $\delta^{13} \mathrm{C}$ values has been documented (0.9-2.6\%o), which was interpreted as reflecting feeding in wetlands where plants do not undergo seasonal water stress. However, wetlands were not part of Chaves's surrounding landscape. Berthon et al. (2018) raise the possibility of winter foddering with summer grass. Furthermore, these results contrast with those provided by the experimental study carried out on transhumant sheep by Tornero et al. (2018) in the same study area. The modern transhumant sheep show a higher amplitude of intra-variation of $\delta^{13} \mathrm{C}$ values than at Chaves $(2.2 \%$ and $3.3 \%$; against $0.44 \%$ to $1.6 \%$ in Chaves sheep) and show opposed variations in $\delta^{13} \mathrm{C}$ and $\delta^{18} \mathrm{O}$ values, what is not observed in Chaves. Therefore, the amplitude of intra-annual changes in $\delta^{13} \mathrm{C}$ values as well as the pattern of co-variation of $\delta^{13} \mathrm{C}$ and $\delta^{18} \mathrm{O}$ values in the sheep teeth at Chaves are not in favour of altitudinal mobility.

Sheep CH Ovis 5 and $\mathrm{CH}$ Ovis 9 (in the part of the crown latest formed) are an exception to this scheme, showing higher seasonal variations and a potential contribution of dry environments or $\mathrm{C}_{4}$ plants in the diet (Fig. 2). Plants from the Chenopodiaceae and Amaranthaceae families (including $\mathrm{C}_{4}$ species) are currently present in these latitudes (Domínguez-Llovería, 2011; Sanz-Elorza, 2009; Tornero et al., 2018). These plants are now mostly located in the arid areas in the lowlands (200-500 $\mathrm{m}$ above sea level), but also in the middle mountains (until $1500 \mathrm{~m}$ above sea level) of the Ebro basin. They were present in the steppes of the Ebro since the Pleistocene, being used as food for livestock during their stay in the lowlands (Domínguez-Llovería, 2011). During the Last Glacial Maximum and Late Glacial Interstadial they had their maximum expansion in the Iberian Peninsula, being part of the steppes that dominated the landscape. Later, they regressed from the beginning of the Holocene with a more humid climate, although they survived in the Ebro basin due to the drier climate (González-Sampériz et al., 2017). These drier landscapes would have existed during the mid-Holocene (Alcolea et al. 2017), such as in the Monegros (Peñuelas et al., 1999; Tornero et al., 2018). CH Ovis 5 and CH Ovis 0 may therefore have been taken to steppe areas within the Ebro basin.

The occurrence of autumn/winter lambing implies mild climatic conditions and adequate availability of forage resources and/or that farmers were able to supplement sheep diet in those periods of lower food availability. At Taï and Gazel, sheep lambing deseasoning is suspected to have been supported by winter foddering using forest resources, in order that sheep reach spring mating with a good body mass (Tornero et al., 2020). At Chaves, no such use of forest resources as winter forage could be evidenced from $\delta^{13} \mathrm{C}$ values, even though 
archaeobotanical data suggest the presence of an open forest during the Early Neolithic period (Alcolea et al., 2017; López-García, 1992; LópezGarcía and López-Sáez, 2000). Alternatively, winter forage could have been collected at the margins of the open forests (where a canopy effect would not apply) or constituted with other types of plants. As mentioned above, it is also possible that the low annual variability in $\delta^{13} \mathrm{C}$ values is explained by the use of summer forage as winter fodder. This hypothesis could be supported by the presence of charcoals from different types of Mediterranean shrubs (Arbutus unedo, Juniperus, Fabaceae and Phillyrea/ Rhamnus) (Alcolea et al., 2017), although these taxa could have had other uses. The use of agricultural by-products, such as stubble cereals, is also possible. This has been observed in traditional Mediterranean livestock farmers, who used to dedicate an important part of their cultivated land to cereals for fodder, which were grazed in late winter and early spring, mowed in late spring for hay or cropped ripe in early summer for grain and straw (Halstead, 2006).

\subsubsection{Microwear}

The degree of abrasion is a fundamental aspect to infer the type of diet ingested by the animal populations. In recent years there has been a debate on whether the origin of these abrasions is found in the diet itself (phytoliths) or are incorporated into it in the form of soil or dust (SchulzKornas et al., 2020). Different experiments showed that the effect of external abrasives depended on their length (Ackermans et al., 2020; Hoffman et al., 2015; Merceron et al., 2016; Schulz-Kornas et al., 2020). In any case, it seems that both types of abrasives matter and should be taken into account.

In the present study, the number of scratches and pits is low for all species, which would correspond to a non-abrasive diet. Feeding from a non-abrasive diet would correspond to a browsing diet according to the classification of Solounias and Semprebon (2002). This would not correspond to the usual preference of the sheep, which tend to prefer pastures (Hofmann, 1989), but in certain environments like the Mediterranean they may be browsers (Bartolomé et al., 1998; Papachristou, 1997; Rogosic et al., 2006; Valderrábano et al., 1996). The same applies to other species such as cattle, which can also browsers in Mediterranean environments (Bartolomé et al., 2011; Brosh et al., 2006; Schoenbaum et al., 2018), or the Iberian ibex, which is mixed feeder depending on plant availability (Acevedo and Cassinello, 2009; Martínez, 2008). Another factor to take into account is that feeding in domestic animals is more difficult to characterize from microwear than that of wild species, due to a greater number of variables to take into account. The control carried out by humans increases the variability in feeding regimes, which can range from free or semi-controlled grazing in a variety of environments to the use of fodder (Mainland, 2006, 2003, 1998a). Further experimental studies are needed to deepen the understanding of the relationship between diet and microwear. One recent study has experimented with different traditional feeding regimes in modern sheep (Gallego-Valle et al., 2020). The diet of the Chaves sheep is less abrasive than the different feeding regimes of modern sheep (alfalfa, ray-grass, forage, barley and dusty alfalfa). Feeding with a high soil content can be ruled out, but it is difficult to classify the type of food ingested. It is interesting to note that diets composed of grasses (raygrass) can also leave a low number of scratches (Gallego-Valle et al., 2020). For this reason, it cannot be ruled out that the diet of the Chaves sheep (and other species such as cattle) was made up of low-abrasive grasses. It is also interesting from this study that the use of cereal straw and grains as hay gives the least abrasive signs, so that feeding with cereal-based fodder cannot be ruled out either.

In any case, at Chaves, the diet of the sheep is not very variable, especially when compared to wild species. This may be due to a more selective type of diet of the sheep with respect to the rest of the animals, or to a close control by herders over the sheep. Also interesting is the differentiated diet of young sheep, showing lower average numbers of scratches compared to adults. Although it is true that the sample for each age category is small, it does seem to indicate a trend towards less abrasive feeding among young sheep. This tendency towards a more selected diet for young animals has also been observed in the microwear studies carried out at La Draga (Sierra et al., 2019). The differences may be due to young and adult sheep grazing in separate areas (Shank, 1982) or young sheep choosing a diet with higher digestibility (Langlands, 1968). Another reason for the different signals may be the seasonality of the slaughter of young animals compared to adults (Rivals and Deniaux, 2005). Last, the difference may be due to a different management of the young animals by humans. The presence of neonatal and infantile individuals in Chaves (Sierra et al., 2019) could be due to the fact that young animals are raised inside the cave and fed forage.

The results show the existence of a good plant cover, since the low abrasiveness of the diet allows ruling out the inclusion of soil elements in the diet (Mainland, 2003). These results are consistent with anthracological data, which reveal a landscape dominated by pine and mixed forests with oaks accompanied by Mediterranean shrubs (Arbutus unedo, Fabaceae and Phillyrea/Rhamnus) (Alcolea et al., 2017), and with pollen analyses, which show a landscape formed by a slightly open forest (Arboreal Pollen 40-60\%) dominated mainly by pines (López-García, 1992; López-García and López-Sáez, 2000). Furthermore, overgrazing could be ruled out due to the scarcity of soil intake, as has been suggested for later periods (Jiménez-Manchón et al., 2018). It is from Early Neolithic that human impact on the environment begins to be detected (Revelles, 2017), so the grasses would still be in good condition. The low number of pits, which would be related to the levels of sand and dust on the leaves consumed (Semprebon and Rivals, 2007), also points to a not very dry climate, which is consistent with the characteristics of the area's climate during the Mid-Holocene (González-Sampériz et al., 2017; Montes et al., 2016).

\section{Conclusions}

The integration of the results of reproduction and diet in the sheep of Chaves brings deeper knowledge into the economic systems of these Early Neolithic pastoral societies in the Iberian Peninsula. The results at Chaves show autumn/winter lambing, which is considered today as "out-of-season" lambing, typical for some Mediterranean breeds and husbandry systems. This extension of births shows a high degree of physiological adaptation to the western Mediterranean environment and climate at the beginning of the Neolithic and that the first herders were able to play an important role by manipulating the interactions between females and males (socio-sexual signals) those reproductive characteristics that were most favourable to them and managed the flocks for reproduction at those times when it was most advantageous for them. This demonstrates the wide zootechnical knowledge of these first farming societies, especially of the reproductive cycles of the sheep, and that these Early Neolithic husbandry systems took advantage of the local environmental factors and resources to extend the lambing period.

On the other hand, the feeding regimes of Chaves' sheep are very little variable, as far as can be shown from $\delta^{13} \mathrm{C}$ and microwear analysis. The $\delta^{13} \mathrm{C}$ values do not show evidence for mobility to the highlands and for the use of forest resources, although the use of open forest could not be shown. These regimes hardly varied both between individuals and within the annual cycle. The results of microwear show that the Chaves sheep had a more controlled feeding than wild animals in the same environment and that they were fed in environments with good plant cover, which would have hardly suffered from human impact. It has not been possible to document fodder feeding in winter, although the low variability of the values on $\delta^{13} \mathrm{C}$ and the low-abrasive diet could be due to this practice (both with forestry resources and agricultural byproducts). Two sheep, one from the later occupation (1a level), and other from early occupation ( $1 \mathrm{~b}$ level) showed seasonal contribution of $\mathrm{C}_{4}$ plants in diet, possibly suggesting pasturing in the driest lowlands of the Ebro basin. This could mean that the sheep would be grazed in the vicinity of the cave for most of the year, and would even be kept there, as it had been previously suggested at Chaves (Sierra et al., 2019), being 
fed on fodder.

\section{CRediT authorship contribution statement}

Alejandro Sierra: Conceptualization, Methodology, Formal analysis, Investigation, Writing - original draft, Writing - review \& editing. Marie Balasse: Conceptualization, Methodology, Formal analysis, Writing - original draft, Writing - review \& editing, Supervision. Florent Rivals: Methodology, Formal analysis, Resources, Supervision, Writing review \& editing. Denis Fiorillo: Methodology, Formal analysis, Investigation. Pilar Utrilla: Data curation, Resources, Funding acquisition. Maria Saña: Conceptualization, Investigation, Writing - review \& editing, Supervision, Funding acquisition, Project administration.

\section{Declaration of Competing Interest}

The authors declare that they have no known competing financial interests or personal relationships that could have appeared to influence the work reported in this paper.

\section{Acknowledgements}

Research has been funded by project HAR2014-60081-R, HAR201788304-P and HAR2014-59042-P of the Spanish Ministry of Science and Innovation. This work has been carried out thanks to the FPI predoctoral grant Ministerio de Economía y Competitividad de España within the framework of the project HAR2014-59042-P. M. S. and A.S. are members of the research Group GRAMPO (2017 SGR 1302) supported by AGAUR, Generalitat de Catalunya. Stable isotope analyses were conducted at the SSMIM (Paris, France). F.R. is member of the research group GAPS (2017 SGR 836) supported by AGAUR, Generalitat de Catalunya and his research is supported by the Spanish Ministry of Science and Innovation through the "María de Maeztu" excellence accreditation (CEX2019-000945-M).

\section{Appendix A. Supplementary data}

Supplementary data to this article can be found online at https://doi. org/10.1016/j.jasrep.2021.102935.

\section{References}

Abecia, J.A., Sosa, C., Forcada, F., Meikle, A., 2006. The effect of undernutrition on the establishment of pregnancy in the ewe. Reprod. Nutr. Dev. 46, 367-378. https://doi. org $/ 10.1051 /$ rnd:2006018.

Acevedo, P., Cassinello, J., 2009. Biology, ecology and status of Iberian ibex Capra pyrenaica: A critical review and research prospectus. Mamm. Rev. 39, 17-32. https://doi.org/10.1111/j.1365-2907.2008.00138.x.

Ackermans, N.L., Winkler, D.E., Martin, L.F., Kaiser, T.M., Clauss, M., Hatt, J.M., 2020 Dust and grit matter: Abrasives of different size lead to opposing dental microwear textures in experimentally fed sheep (Ovis aries). J. Exp. Biol. 223 https://doi.org/ 10.1242/jeb.220442.

Alcolea, M., Utrilla, P., Piqué, R., Laborda, R., Mazo, C., 2017. Fuel and acorns: Early Neolithic plant use from Cueva de Chaves (NE Spain). Quat. Int. 457, 228-239. https://doi.org/10.1016/j.quaint.2016.10.019.

Antolín, F., 2016. Local, intensive and diverse?: Early farmers and plant economy in the North-East of the Iberian Peninsula (5500-2300 cal BC). Barkhuis.

Antolín, F., 2015. Entre agricultores primitivos, cultivos de rozas y pastores transhumantes. Una mirada crítica a los modelos económicos propuestos para los grupos neolíticos del noreste peninsular y una aportación desde el registro carpológico. Rev. d'Arqueologia Ponent 25, 11-45.

Antolín, F., Buxó, R., Jacomet, S., Navarrete, V., Saña, M., 2014. An integrated perspective on farming in the early Neolithic lakeshore site of La Draga (Banyoles, Spain). Environ. Archaeol. 19, 241-255. https://doi.org/10.1179/ 1749631414Y.0000000027.

Antolín, F., Navarrete, V., Saña, M., Viñerta, Á., Gassiot, E., 2018. Herders in the mountains and farmers in the plains? A comparative evaluation of the archaeobiological record from Neolithic sites in the eastern Iberian Pyrenees and the southern lower lands. Quat. Int. https://doi.org/10.1016/j.quaint.2017.05.056.

Balasse, M., Ambrose, S.H., 2005. Distinguishing sheep and goats using dental morphology and stable carbon isotopes in C4 grassland environments. J. Archaeol. Sci. 32, 691-702. https://doi.org/10.1016/J.JAS.2004.11.013.
Balasse, M., Ambrose, S.H., Smith, A.B., Price, T.D., 2002. The Seasonal Mobility Model for Prehistoric Herders in the South-western Cape of South Africa Assessed by Isotopic Analysis of Sheep Tooth Enamel. J. Archaeol. Sci. 29, 917-932. https://doi. org/10.1006/JASC.2001.0787.

Balasse, M., Keller, M., Bǎlăşescu, A., Tresset, A., Chemineau, P., 2017a. Cycle de reproduction des ovins et rythme saisonnier de l'élevage: un schéma plurimillénaire bouleversé par la recherche agronomique, in: Balasse, Marie, Dillmann, P. (Eds.), Regards Croisés: Quand Les Sciences Archéologiques Rencontrent l'innovation. Archives contemporaines, pp. 25-50.

Balasse, M., Obein, G., Ughetto-Monfrin, J., Mainland, I., 2012. Investigating seasonality and season of birth in past herds: A reference set of sheep enamel stable oxygen isotope ratios. Archaeometry 54, 349-368. https://doi.org/10.1111/j.14754754.2011.00624.x.

Balasse, M., Renault-Fabregon, L., Gandois, H., Fiorillo, D., Gorczyk, J., Bacvarov, K., Ivanova, M., 2020. Neolithic sheep birth distribution: Results from Nova Nadezhda (sixth millennium BC, Bulgaria) and a reassessment of European data with a new modern reference set including upper and lower molars. J. Archaeol. Sci. 118 https://doi.org/10.1016/j.jas.2020.105139.

Balasse, M., Smith, A.B., Ambrose, S.H., Leigh, S.R., 2003. Determining sheep birth seasonality by analysis of tooth enamel oxygen isotope ratios: The late stone age site of Kasteelberg (South Africa). J. Archaeol. Sci. 30, 205-215. https://doi.org/ 10.1006/jasc.2002.0833.

Balasse, M., Tresset, A., Bălăşescu, A., Blaise, E., Tornero, C., Gandois, H., Fiorillo, D. Nyerges, E.A., Frémondeau, D., Banffy, E., Ivanova, M., 2017b. Animal Board Invited Review: Sheep birth distribution in past herds: A review for prehistoric Europe (6th to 3rd millennia BC). Animal 11, 2229-2236. https://doi.org/10.1017/ S1751731117001045.

Baldellou, V., 2012. La Cueva de Chaves (Bastarás-Casbas, Huesca). Saguntum Extra 12, 141-144.

Bartolomé, J., Franch, J., Plaixats, J., Seligman, N.G., 1998. Diet selection by sheep and goats on Mediterranean heath-woodland range. J. Range Manag. 51, 383-391. https://doi.org/10.2307/4003322.

Bartolomé, J., Plaixats, J., Piedrafita, J., Fina, M., Adrobau, E., Aixàs, A., Bonet, M., Grau, J., Polo, L., 2011. Foraging behavior of Alberes cattle in a Mediterranean forest ecosystem. Rangel. Ecol. Manag. 64, 319-324. https://doi.org/10.2111/REM-D-0900160.1 .

Berthon, R., Kovačiková, L., Tresset, A., Balasse, M., 2018. Integration of Linearbandkeramik cattle husbandry in the forested landscape of the mid-Holocene climate optimum: Seasonal-scale investigations in Bohemia. J. Anthropol. Archaeol. 51, 16-27. https://doi.org/10.1016/j.jaa.2018.05.002.

Blaise, E., Balasse, M., 2011. Seasonality and season of birth of modern and late Neolithic sheep from south-eastern France using tooth enamel 8180 analysis. J. Archaeol. Sci. https://doi.org/10.1016/j.jas.2011.07.007.

Boessneck, J., Von den Driesch, A., 1980. Studien über frühe Tierknochenfunde von der Iberschen Halbinsel. Deutsches Archäologisches Institut Abteilung 7, Madrid.

Bonafini, M., Pellegrini, M., Ditchfield, P., Pollard, A.M., 2013. Investigation of the "canopy effect" in the isotope ecology of temperate woodlands. J. Archaeol. Sci. 40 https://doi.org/10.1016/j.jas.2013.03.028.

Brosh, A., Henkin, Z., Orlov, A., Aharoni, Y., 2006. Diet composition and energy balance of cows grazing on Mediterranean woodland. Livest. Sci. 102, 11-22. https://doi. org/10.1016/j.livprodsci.2005.11.016.

Camarós, E., Sánchez-Hernández, C., Rivals, F., 2016. Make it clear: molds, transparent casts and lightning techniques for stereomicroscopic analysis of taphonomic modifications on bone surfaces. J. Anthropol. Sci. = Riv. di Antropol. JASS 94, 223-230. https://doi.org/10.4436/JASS.94023.

Castaños, P., 2004. Estudio arqueozoológico de los macromamíferos del Neolítico de la cueva de Chaves (Huesca). SALDVIE.

Cerling, T.E., Wang, Y., Quade, J., 1993. Expansion of C4 ecosystems as an indicator of global ecological change in the late Miocene. Nature 361. https://doi.org/10.1038/ $361344 \mathrm{a} 0$.

Chemineau, P., 1993. Medio ambiente y reproducción animal. World Anim. Rev. 77, $2-14$.

Chemineau, P., Guillaume, D., Migaud, M., Thiéry, J.C., Pellicer-Rubio, M.T., Malpaux, B., 2008. Seasonality of Reproduction in Mammals: Intimate Regulatory Mechanisms and Practical Implications. Reprod. Domest. Anim. 43, 40-47. https:// doi.org/10.1111/j.1439-0531.2008.01141.x.

Debono Spiteri, C., Gillis, R.E., Roffet-Salque, M., Navarro, L.C., Guilaine, J., Manen, C., Muntoni, I.M., Segui, M.S., Urem-Kotsou, D., Whelton, H.L., Craig, O.E., Vigne, J.-D., Evershed, R.P., 2016. Regional asynchronicity in dairy production and processing in early farming communities of the northern Mediterranean. Proc. Natl. Acad. Sci. 113, 13594-13599. https://doi.org/10.1073/PNAS.1607810113.

Domínguez-Llovería, J.A., 2011. De galachos, yesos y muelas. El singular entorno natural de Zaragoza, in: Aguilera, I., Ona, J.L. (Eds.), Delimitación Comarcal de Zaragoza. Departamento de Política Territorial, Justicia e Interior, Gobierno de Aragón, Zaragoza, pp. 35-60.

Drucker, D.G., Bocherens, H., 2009. Carbon stable isotopes of mammal bones as tracers of canopy development and habitat use in temperate and boreal contexts, in: Forest Canopies: Forest Production, Ecosystem Health and Climate Conditions.

Drucker, D.G., Bridault, A., Hobson, K.A., Szuma, E., Bocherens, H., 2008. Can carbon-13 in large herbivores reflect the canopy effect in temperate and boreal ecosystems? Evidence from modern and ancient ungulates. Palaeogeogr. Palaeoclimatol. Palaeoecol. 266, 69-82. https://doi.org/10.1016/j.palaeo.2008.03.020.

El-Zaatari, S., 2010. Occlusal microwear texture analysis and the diets of historical/ prehistoric hunter-gatherers. Int. J. Osteoarchaeol. 20, 67-87. https://doi.org/ 10.1002/oa.1027. 
Fernández-Otal, J.A., 1993. La Casa de Ganaderos de Zaragoza: derecho y trashumancia a fines del siglo XV. Institución Fernando el Católico, Zaragoza.

Forcada, F., Abecia, J.A., Sierra, I., 1992. Seasonal changes in oestrus activity and ovulation rate in Rasa Aragonesa ewes maintained at two different body condition levels. Small Rumin. Res. 8, 313-324. https://doi.org/10.1016/0921-4488(92) 90212-M.

Gallego-Valle, A., Colominas, L., Burguet-Coca, A., Aguilera, M., Palet, J.M., Tornero, C., 2020. What is on the menu today? Creating a microwear reference collection through a controlled-food trial to study feeding management systems of ancient agropastoral societies. Quat. Int. https://doi.org/10.1016/j.quaint.2020.02.020.

Gallego, A., Rivals, F., Colominas, L., Palet, J.M., 2017. Pastando en las marismas. Una aproximación desde la técnica del microdesgaste dentario a la alimentación del ganado ovino en el Empordà romano (noreste de la Península Ibérica). Pyrenae 48 93-113. https://doi.org/10.1344/Pyrenae2017.vol48num1.4.

Gillis, R., Chaix, L., Vigne, J.-D., 2011. An assessment of morphological criteria for discriminating sheep and goat mandibles on a large prehistoric archaeological assemblage (Kerma, Sudan). J. Archaeol. Sci. 38, 2324-2339. https://doi.org/ 10.1016/J.JAS.2011.04.012.

Gómez-Brunet, A., Santiago-Moreno, J., Toledano-Diaz, A., López-Sebastián, A., 2012. Reproductive seasonality and its control in spanish sheep and goats. Trop. Subtrop. Agroecosystems.

González-Sampériz, P., Aranbarri, J., Pérez-Sanz, A., Gil-Romera, G., Moreno, A., Leunda, M., Sevilla-Callejo, M., Corella, J.P., Morellón, M., Oliva, B., ValeroGarcés, B., 2017. Environmental and climate change in the southern Central Pyrenees since the Last Glacial Maximum: A view from the lake records. Catena. https://doi.org/10.1016/j.catena.2016.07.041.

Grine, F.E., 1986. Dental evidence for dietary differences in Australopithecus and Paranthropus: a quantitative analysis of permanent molar microwear. J. Hum. Evol. 15, 783-822. https://doi.org/10.1016/S0047-2484(86)80010-0.

Hadjikoumis, A., Vigne, J.-D., Simmons, A., Guilaine, J., Fiorillo, D., Balasse, M., 2018. Autumn/winter births in traditional and Pre-Pottery Neolithic caprine husbandry in Cyprus: Evidence from ethnography and stable isotopes. J. Anthropol. Archaeol. 53, 102-111. https://doi.org/10.1016/J.JAA.2018.12.001.

Hafez, E.E.S., 1952. Studies on the breeding season and reproduction of the ewe Part I The breeding season in different environments Part II. The breeding season in one locality. J. Agric. Sci. https://doi.org/10.1017/S0021859600056896.

Halstead, P., 2006. Sheep in the garden: the integration of crop and livestock husbandry in early farming regimes of Greece and Southern Europe. In: Serjeantson, D., Field, D. (Eds.), Animals in the Neolithic of Britain and Europe. Oxbow Books, Oxford, pp. 42-55.

Halstead, P., 1996. Pastoralism or household herding? problems of scale and specialization in early Greek animal husbandry. World Archaeol. 28, 20-42. https:// doi.org/10.1080/00438243.1996.9980329.

Halstead, P., 1981. Counting sheep in Neolithic and Bronze age Greece. In: Hodder, I. Isaac, G., Hammond, N. (Eds.), Pattern of the Past: Studies in Honour of David Clarke. Cambridge University Press, Cambridge, pp. 85-96.

Halstead, P., Collins, P., Isaakidou, V., 2002. Sorting the sheep from the goats: Morphological distinctions between the mandibles and mandibular teeth of adult Ovis and Capra. J. Archaeol. Sci. 29, 545-553. https://doi.org/10.1006/ jasc. 2001.0777.

Helmer, D., 2000. Discrimination des genres Ovis et Capra à l'aide des prémolaires inférieures 3 et 4 et interprétation des âges d'abattage : l'exemple de Dikili Tash (Grèce). Anthropozoologica 31, 29-38.

Helmer, D., Blaise, É., Gourichon, L., Saña, M., 2018. Using cattle for traction and transport during the Neolithic period: contribution of the study of the first and second phalanxes. Bull. la Société préhistorique française 115 (1), 71-98.

Hoffman, J.M., Fraser, D., Clementz, M.T., 2015. Controlled feeding trials with ungulates: a newapplication of in vivo dental molding to assess the abrasive factors of microwear. J. Exp. Biol. 218, 1538-1547. https://doi.org/10.1242/jeb.118406.

Hofmann, R.R., 1989. Evolutionary steps of ecophysiological adaptation and diversification of ruminants: a comparative view of their digestive system. Oecologia 78. https://doi.org/10.1007/BF00378733.

Iacumin, P., Longinelli, A., 2002. Relationship between $\delta 180$ values for skeletal apatite from reindeer and foxes and yearly mean $\delta 180$ values of environmental water. Earth Planet. Sci. Lett. 201, 213-219. https://doi.org/10.1016/S0012-821X(02)00635-0.

Jiménez-Manchón, S., Blaise, É., Gardeisen, A., 2020. Exploring low-magnification dental microwear of domestic ungulates: Qualitative observations to infer palaeodiets. Quat. Int. https://doi.org/10.1016/j.quaint.2020.02.021.

Jiménez-Manchón, S., Valenzuela-Lamas, S., Cáceres, I., Orengo, H., Gardeisen, A. López, D., Rivals, F., 2018. Reconstruction of Caprine Management and Landscape Use Through Dental Microwear Analysis: The Case of the Iron Age Site of El Turó de la Font de la Canya (Barcelona, Spain). Environ. Archaeol. 1-11 https://doi.org/ 10.1080/14614103.2018.1486274.

Jones, G.G., 2006. Tooth Eruption and Wear Observed in Live Sheep from Butser Hill, the Cotswold Farm Park and Five Farms in the. In: Pentland Hills, U.K., in: Ruscillo, D., (Eds.), Recent Advances in Ageing and Sexing Animal Bones. Oxbow Books, Oxford, pp. 155-178. https://doi.org/10.2307/j.ctvh1ds02.14.

Karsch, F.J., Bittman, E.L., Foster, D.L., Goodman, R.L., Legan, S.J., Robinson, J.E., 1984. Neuroendocrine basis of seasonal reproduction. Recent Prog. Horm. Res. https://doi. org/10.1016/b978-0-12-571140-1.50010-4.

Kilgour, R.J., Waterhouse, T., Dwyer, C.M., Ivanov, I.D., 2008. Farming Systems for Sheep Production and Their Effect on Welfare. In: Dwyer, C.M. (Ed.), The Welfare of Sheep. Springer, Dordrecht, pp. 213-265. https://doi.org/10.1007/978-1-40208553-6_6.
Kind, K.L., Moore, V.M., Davies, M.J., 2006. Diet around conception and during pregnancy - Effects on fetal and neonatal outcomes. Reprod. Biomed. Online 12, 532-541. https://doi.org/10.1016/S1472-6483(10)61178-9.

King, T., Andrews, P., Boz, B., 1999. Effect of taphonomic processes on dental microwear. Am. J. Phys. Anthropol. 108, 359-373. https://doi.org/10.1002/(SICI)1096-8644 (199903)108:3<359::AID-AJPA10>3.0.CO;2-9.

Kohn, M.J., 2010. Carbon isotope compositions of terrestrial C3 plants as indicators of (paleo)ecology and (paleo)climate. Proc. Natl. Acad. Sci. U. S. A. 107, 19691-19695. https://doi.org/10.1073/pnas.1004933107.

Lamy, E., Van Harten, S., Sales-Baptista, E., Guerra, M.M.M., De Almeida, A.M., 2012. Factors influencing livestock productivity. In: Environmental Stress and Amelioration in Livestock Production. Springer-Verlag, Berlin Heidelberg, pp. 19-51. https://doi.org/10.1007/978-3-642-29205-7_2.

Langlands, J.P., 1968. The feed intake of grazing sheep differing in age, breed, previous nutrition and live weight. J. Agric. Sci. 71, 167-172. https://doi.org/10.1017/ S002185960001460X.

Lee-Thorp, J.A., van der Merwe, N.J., 1991. Aspects of the chemistry of modern and fossil biological apatites. J. Archaeol. Sci. 18, 343-354. https://doi.org/10.1016/ 0305-4403(91)90070-6.

Liesau, C., Morales, A., 2012. Las transformaciones económicas del Neolítico en la Península Ibérica la ganadería, in: Rojo-Guerra, M.A., Garrido Pena, R., García Martínez De Lagrán, Í. (Eds.), El Neolítico En La Península Ibérica y Su Contexto Europeo. Cátedra, pp. 107-128.

Longinelli, A., 1984. Oxygen isotopes in mammal bone phosphate: A new tool for paleohydrological and paleoclimatological research? Geochim. Cosmochim. Acta 48, 385-390. https://doi.org/10.1016/0016-7037(84)90259-X.

López-García, P., 1992. Analisis polínicos de cuatro yacimientos arqueológicos situados en el Bajo Aragón, in: Utrilla, P. (Ed.), Aragón/Litoral Mediterráneo. Intercambios Culturales Durante La Prehistoria. Institución Fernando el Católico, Zaragoza, pp. 235-242.

López-García, P., López-Sáez, J.A., 2000. Le paysage et la phase ÉpipaléolithiqueMésolithique dans les Pré-Pyrénées Aragonaises et le Bassin Moyen de l'Èbre à partir de l'analyse palynologique, in: Les Derniers Chasseurs Cueilleurs d'Europe Occidentale (13.000-5.5000 Av JC). pp. 59-69.

Luz, B., Kolodny, Y., Horowitz, M., 1984. Fractionation of oxygen isotopes between mammalian bone-phosphate and environmental drinking water. Geochim. Cosmochim. Acta. https://doi.org/10.1016/0016-7037(84)90338-7.

Mainland, I.L., 2006. Pastures lost? A dental microwear study of ovicaprine diet and management in Norse Greenland. J. Archaeol. Sci. 33, 238-252. https://doi.org/ 10.1016/j.jas.2005.07.013.

Mainland, I.L., 2003. Dental microwear in grazing and browsing Gotland sheep (Ovis aries) and its implications for dietary reconstruction. J. Archaeol. Sci. 30, 1513-1527. https://doi.org/10.1016/S0305-4403(03)00055-4.

Mainland, I.L., 1998a. Dental microwear and diet in domestic sheep (Ovis aries) and goats (Capra Hircus): Distinguishing grazing and fodder-fed ovicaprids using a quantitative analytical approach. J. Archaeol. Sci. 25, 1259-1271. https://doi.org/ 10.1006/jasc.1998.0301.

Mainland, I.L., 1998b. The Lamb's Last Supper: the Role of Dental Microwear Analysis in Reconstructing Livestock Diet in the Past. Environ. Archaeol. 1, 55-62. https://doi. org/10.1179/env.1996.1.1.55.

Martínez, T., 2008. Role of Various Woody Species in Spanish Mediterranean Forest and Scrubland as Food Resources for Spanish Ibex (Capra pyrenaica Schinz) and Red Deer (Cervus elaphus L.), in: Rigueiro-Rodríguez, A., McAdam, J., Mosquera-Losada, M.R. (Eds.), Agroforestry in Europe. Springer, Dordrecht, pp. 233-253. https://doi. org/10.1007/978-1-4020-8272-6_11.

Meikle, A., de Brun, V., Carriquiry, M., Soca, P., Sosa, C., Adrien, M. de L., Chilibroste, P., Abecia, J.A., 2018. Influences of nutrition and metabolism on reproduction of the female ruminant. Anim. Reprod. 15, 899-911. https://doi.org/10.21451/19843143-AR2018-0017.

Merceron, G., Ramdarshan, A., Blondel, C., Boisserie, J.R., Brunetiere, N., Francisco, A., Gautier, D., Milhet, X., Novello, A., Pret, D., 2016. Untangling the environmental from the dietary: Dust does not matter. Proc. R. Soc. B Biol. Sci. 283, 20161032. https://doi.org/10.1098/rspb.2016.1032.

Milhaud, G., Nezit, J., 1991. Développement des molaires chez le Mouton: Étude morphologique, radiographique et microdurométrique. Rec. Med. Vet. Ec. Alfort. Développement des molaires chez le mouton Études morphologique, radiographique et microdurométrique $167,121-127$.

Montes, L., Domingo, R., González-Sampériz, P., Sebastián, M., Aranbarri, J., Castaños, P., García-Simón, L.M., Alcolea, M., Laborda, R., 2016. Landscape, resources and people during the Mesolithic and Neolithic times in NE Iberia: The Arba de Biel Basin. Quat. Int. 403, 133-150. https://doi.org/10.1016/j. quaint.2015.05.041.

Morand-Fehr, P., Fedele, V., Decandia, M., Le Frileux, Y., 2007. Influence of farming and feeding systems on composition and quality of goat and sheep milk. Small Rumin. Res. 68, 20-34. https://doi.org/10.1016/j.smallrumres.2006.09.019.

Navarrete, V., Colonese, A.C., Tornero, C., Antolín, F., Von Tersch, M., Eulàlia Subirà, M., Comes, P., Rosell-Melé, A., Saña, M., 2017. Feeding Management Strategies among the Early Neolithic Pigs in the NE of the Iberian Peninsula. Int. J. Osteoarchaeol. 27, 839-852. https://doi.org/10.1002/oa.2598.

Navarrete, V., Tornero, C., Balasse, M., Saña, M., 2019. Food management of early introduced caprine and bovine herds in the early Neolithic site of La Draga (Banyoles): An isotopic approach. Int. J. Osteoarchaeol. 29, 986-998. https://doi. org/10.1002/oa.2812.

Noe-Nygaard, N., Price, T.D., Hede, S.U., 2005. Diet of aurochs and early cattle in southern Scandinavia: Evidence from $15 \mathrm{~N}$ and $13 \mathrm{C}$ stable isotopes. J. Archaeol. Sci. https://doi.org/10.1016/j.jas.2005.01.004. 
Papachristou, T.G., 1997. Foraging behaviour of goats and sheep on Mediterranean kermes oak shrublands. Small Rumin. Res. 24, 85-93. https://doi.org/10.1016/ S0921-4488(96)00942-X.

Payne, S., 1987. Reference codes for wear states in the mandibular cheek teeth of sheep and goats. J. Archaeol. Sci. 14, 609-614. https://doi.org/10.1016/0305-4403(87) 90079-3.

Payne, S., 1985. Morphological distinctions between the mandibular teeth of young sheep, Ovis, and goats. Capra. J. Archaeol. Sci. 12, 139-147. https://doi.org/ 10.1016/0305-4403(85)90058-5.

Payne, S., 1973. Kill-off Patterns in Sheep and Goats: the Mandibles from Aşvan Kale. Anatol. Stud. 23, 281-303. https://doi.org/10.2307/3642547.

Peñuelas, J., Filella, I., Terradas, J., 1999. Variability of plant nitrogen and water use in a $100-\mathrm{m}$ transect of a subdesertic depression of the Ebro valley (Spain) characterized by leaf $\delta 13 \mathrm{C}$ and $\delta 15 \mathrm{~N}$. Acta Oecologica 20. https://doi.org/10.1016/S1146-609X (99)80024-1.

Pérez Ripoll, M., 1980. La fauna de vertebrados, in: Marti Oliver, B., Pascual, V., Gallart, M., López-García, P., Pérez-Ripoll, M., Acuña, J., Robles, F. (Eds.), Cova de l'Or (Beniarrés-Alicante). Vol. II. Servicio de Investigacion Prehistorica. Serie de Trabajos Varios Valencia, 65, Valencia, pp. 193-255.

Pyankov, V.I., Ziegler, H., Akhani, H., Deigele, C., Lüttge, U., 2010. European plants with C4 photosynthesis: Geographical and taxonomic distribution and relations to climate parameters. Bot. J. Linn. Soc. 163 https://doi.org/10.1111/j.10958339.2010.01062.x.

Redding, R.W., 1981. Decision making in subsistence herding of sheep and goats in the Middle East. University of Michigan.

Revelles, J., 2017. Archaeoecology of Neolithisation. Human-environment interactions in the NE Iberian Peninsula during the Early Neolithic. J. Archaeol. Sci. Reports 15. https://doi.org/10.1016/j.jasrep.2016.02.004.

Rivals, F., 2019. MicrowearBivaR: a code to create tooth microwear bivariate plots in R. https://doi.org/10.5281/ZENODO.2587575.

Rivals, F., Deniaux, B., 2005. Investigation of human hunting seasonality through dental microwear analysis of two Caprinae in late Pleistocene localities in Southern France. J. Archaeol. Sci. 32, 1603-1612. https://doi.org/10.1016/j.jas.2005.04.014.

Rivals, F., Gardeisen, A., Cantuel, J., 2011. Domestic and wild ungulate dietary traits at Kouphovouno (Sparta, Greece): Implications for livestock management and paleoenvironment in the Neolithic. J. Archaeol. Sci. 38, 528-537. https://doi.org/ 10.1016/j.jas.2010.10.007.

Rivals, F., Schulz, E., Kaiser, T.M., 2009. Late and middle Pleistocene ungulates dietary diversity in Western Europe indicate variations of Neanderthal paleoenvironments through time and space. Quat. Sci. Rev. 28 https://doi.org/10.1016/j. quascirev.2009.09.004.

Rogosic, J., Pfister, J.A., Provenza, F.D., Grbesa, D., 2006. Sheep and goat preference for and nutritional value of Mediterranean maquis shrubs. Small Rumin. Res. 64, 169-179. https://doi.org/10.1016/j.smallrumres.2005.04.017.

Rosa, H.J.D., Bryant, M.J., 2003. Seasonality of reproduction in sheep. Small Rumin. Res. https://doi.org/10.1016/S0921-4488(03)00038-5.

Saña, M., 2013. Domestication of Animals in the Iberian Peninsula, in: Colledge, S., Conolly, J., Dobney, K., Manning, K., Shennan, S. (Eds.), The Origins and Spread of Domestic Animals in Southwest Asia and Europe. Left Coast Press, pp. 195-220.

Saña, M., 2011. La gestió dels recursos animals, in: Bosch, À., Chinchilla, J., Tarrús, J. (Eds.), El Poblat Lacustre Del Neolític Antic de La Draga, Excavacions 2000-2005. Monografies del CASC 9, Girona, pp. 50-64.

Saña, M., Antolín, F., Alcántara, R., Sierra, A., Tornero, C., 2020. Integrating domesticates: earliest farming experiences in the Iberian Peninsula., in: Gron, K., Rowley-Conwy, P., Sørensen, L. (Eds.), Farmers at the Frontier: A Pan-European Perspective on Neolithisation. Oxbow Books, Oxford, pp. 161-175.

Santiago-Moreno, J., Gómez-Brunet, A., Toledano-Díaz, A., Picazo, R., Gonzalez-Bulnes, A., López-Sebastián, A., 2006. Seasonal endocrine changes and breeding activity in Mediterranean wild ruminants, in: Reproduction in Domestic Animals. https://doi. $\operatorname{org} / 10.1111 / \mathrm{j} .1439-0531.2006 .00771 . x$.

Sanz-Elorza, M., 2009. Flora y vegetación arvense y ruderal de la provincia de Huesca. Jolube, Jaca.

Schoenbaum, I., Henkin, Z., Yehuda, Y., Voet, H., Kigel, J., 2018. Cattle foraging in Mediterranean oak woodlands - Effects of management practices on the woody vegetation. For. Ecol. Manage. 419-420, 160-169. https://doi.org/10.1016/j. foreco.2018.03.017.
Schulz-Kornas, E., Winkler, D.E., Clauss, M., Carlsson, J., Ackermans, N.L., Martin, L.F., Hummel, J., Müller, D.W.H., Hatt, J.M., Kaiser, T.M., 2020. Everything matters: Molar microwear texture in goats (Capra aegagrus hircus) fed diets of different abrasiveness. Palaeogeogr. Palaeoclimatol. Palaeoecol. 552, 109783 https://doi.org/ 10.1016/j.palaeo.2020.109783.

Semprebon, G.M., Rivals, F., 2007. Was grass more prevalent in the pronghorn past? An assessment of the dietary adaptations of Miocene to Recent Antilocapridae (Mammalia: Artiodactyla). Palaeogeogr. Palaeoclimatol. Palaeoecol. 253 https:// doi.org/10.1016/j.palaeo.2007.06.006.

Shank, C.C., 1982. Age-sex differences in the diets of wintering Rocky Mountain bighorn sheep. Ecology 63, 627-633. https://doi.org/10.2307/1936781.

Sierra, A., Bréhard, S., Montes, L., Utrilla, P., Saña, M., 2019. Sheep exploitation and husbandry in first farming societies: from production to consumption in Central Pyrenees in the Early Neolithic. Archaeol. Anthropol. Sci. 11, 5813-5829. https:// doi.org/10.1007/s12520-019-00907-3.

Solounias, N., Semprebon, G., 2002. Advances in the Reconstruction of Ungulate Ecomorphology with Application to Early Fossil Equids. Am. Museum Novit. 2002, 1-49. https://doi.org/10.1206/0003-0082(2002)366<0001:aitrou>2.0.co;2.

Tieszen, L.L., 1991. Natural variations in the carbon isotope values of plants: Implications for archaeology, ecology, and paleoecology. J. Archaeol. Sci. 18 https://doi.org/10.1016/0305-4403(91)90063-U.

Tornero, C., Aguilera, M., Ferrio, J.P., Arcusa, H., Moreno-García, M., Garcia-Reig, S., Rojo-Guerra, M., 2018. Vertical sheep mobility along the altitudinal gradient through stable isotope analyses in tooth molar bioapatite, meteoric water and pastures: A reference from the Ebro valley to the Central Pyrenees. Quat. Int. 484, 94-106. https://doi.org/10.1016/J.QUAINT.2016.11.042.

Tornero, C., Bălășescu, A., Ughetto-Monfrin, J., Voinea, V., Balasse, M., 2013. Seasonality and season of birth in early Eneolithic sheep from Cheia (Romania): Methodological advances and implications for animal economy. J. Archaeol. Sci. 40, 4039-4055. https://doi.org/10.1016/j.jas.2013.05.013.

Tornero, C., Balasse, M., Bréhard, S., Carrère, I., Fiorillo, D., Guilaine, J., Vigne, J.-D., Manen, C., 2020. Early evidence of sheep lambing de-seasoning in the Western Mediterranean in the sixth millennium BCE. Sci. Rep. 10, 12798. https://doi.org/ 10.1038/s41598-020-69576-w.

Utrilla, P., Baldellou, V., 2007. Les galets peints de la grotte de Chaves. Préhistoire, Arts Soc. $62,73-88$.

Utrilla, P., Baldellou, V., 2001. Cantos pintados neolíticos de la cueva de Chaves (Bastarás, Huesca). Saldvie Estud. Prehist. y Arqueol. 2, 45-126.

Utrilla, P., Laborda, R., 2018. La cueva de Chaves (Bastarás, Huesca): 15000 años de ocupación prehistórica. Trab. Prehist. https://doi.org/10.3989/tp.2018.12214.

Utrilla, P., Lorenzo, J., Baldellou, V.-I.C. del, 2008, U., 2008. Enterramiento masculino en fosa, cubierto de cantos rodados, en el Neolítico antiguo de la Cueva de Chaves, in: Hernández, M.S., Soler, J.A., López, J. (Eds.), IV Congreso Del Neolítico Peninsular (27-30 de Noviembre de 2006). MARQ, Diputación Provincial de Alicante. Vol. II, Alicante, pp. 131-140.

Valderrábano, J., Muñoz, F., Delgado, I., 1996. Browsing ability and utilization by sheep and goats of Atriplex halimus L. shrubs. Small Rumin. Res. 19, 131-136. https://doi. org/10.1016/0921-4488(95)00754-7.

Valls Ortiz, M., 1983. Frequent lambing of sheep flocks in Spain: productivity and management consequences. Livest. Prod. Sci. 10 https://doi.org/10.1016/0301 6226(83)90006-4.

van der Merwe, N.J., Medina, E., 1991. The canopy effect, carbon isotope ratios and foodwebs in amazonia. J. Archaeol. Sci. 18, 249-259. https://doi.org/10.1016/ 0305-4403(91)90064-V.

Villalba-Mouco, V., Utrilla, P., Laborda, R., Lorenzo, J.I., Martínez-Labarga, C., SalazarGarcía, D.C., 2018. Reconstruction of human subsistence and husbandry strategies from the Iberian Early Neolithic: A stable isotope approach. Am. J. Phys. Anthropol. https://doi.org/10.1002/ajpa.23622.

Vogel, J., 1978. Isotopic assessment of the dietary habits of ungulates. S. Afr. J. Sci.

Weinreb, M.M., Sharav, Y., 1966. Tooth development in sheep. Dent. Mag. Oral Top. 83.

Werner, C., Máguas, C., 2010. Carbon isotope discrimination as a tracer of functional traits in a mediterranean macchia plant community. Funct. Plant Biol. 37 https:// doi.org/10.1071/FP09081.

Zeder, M.A., Pilaar, S.E., 2010. Assessing the reliability of criteria used to identify mandibles and mandibular teeth in sheep, Ovis, and goats. Capra. J. Archaeol. Sci. 37, 225-242. https://doi.org/10.1016/j.jas.2009.10.002. 